\title{
Unmixing the Mess: Resolving the Circuit Split Over the Brillhart/Wilton Doctrine and Mixed Complaints
}

Wm. Grayson Lambert*

INTRODUCTION

Some issues of federal jurisdiction are well settled. For instance, courts and scholars readily agree that federal courts are courts of limited jurisdiction. ${ }^{1}$ Hence, a federal court may not decide a case over which it lacks subject-matter jurisdiction. ${ }^{2}$

Other issues, however, are not so settled. When federal courts must exercise the jurisdiction granted to them is one such issue without nearly as much consensus. The Supreme Court has adopted various abstention doctrines that allow federal courts to choose not to exercise their jurisdiction. ${ }^{3}$ The Court has, for instance, granted federal courts wide discretion to decline to exercise jurisdiction in cases seeking declaratory relief, a doctrine known as the Brillhart/Wilton doctrine, named for the two cases on which it is based: Brillhart v. Excess Insurance Co. of America ${ }^{4}$ and Wilton v. Seven Falls Co. ${ }^{5}$ The Court has permitted courts far more limited discretion to decline to hear cases involving claims for

* William Grayson Lambert, Duke University School of Law, J.D. 2012; University of Virginia, B.A. 2009. Associate, McGuireWoods LLP.

1. See, e.g., Kokkonen v. Guardian Life Ins. Co. of Am., 511 U.S. 375, 377 (1994) ("Federal courts are courts of limited jurisdiction. They possess only that power authorized by Constitution and statute, which is not to be expanded by judicial decree." (internal citations omitted)); Matthew J. Richardson, Clarifying and Limiting Fraudulent Joinder, 58 FLA. L. REV. 119, 165 (2006) ("It is axiomatic that the federal courts are courts of limited jurisdiction ....").

2. See, e.g., Means v. Stocker, 49 F. Supp. 2d 1047, 1048-49 (W.D. Tenn. 1998) (“Absent subject matter jurisdiction, the Court has no authority to rule on the merits of the claim." (citing Bell v. Hood, 327 U.S. 678, 682 (1946); Moir v. Greater Cleveland Reg'l Transit Auth., 895 F.2d 266, 269 (6th Cir. 1990))).

3. See, e.g., Richard H. Fallon, JR., John F. Manning, Daniel J. Meltzer \& David L. Shapiro, Hart and Wechsler's The Federal Courts and The Federal System 1049-151 (6th ed. 2009) (discussing various abstention doctrines).

4. Brillhart v. Excess Ins. Co. of Am., 316 U.S. 491 (1942).

5. Wilton v. Seven Falls Co., 515 U.S. 277 (1995). 
nondeclaratory relief, ${ }^{6}$ permitting abstention only in "exceptional circumstances."7 But which standard applies when a complaint seeks both types of relief - that is, in a mixed-complaint case?

This question of mixed-complaint cases typically arises in the same type of scenario: A case is pending in a state court, and a litigant in that case (presumably the defendant) files another case in a federal court, based on similar - or even identical — issues as those in the alreadypending state court case. In this new suit, the litigant (now the plaintiff) seeks both declaratory and nondeclaratory relief. The defendant in the new case then asks the court to refrain from deciding that case, based on the earlier-filed case. The court must then decide what standardColorado River or Brillhart/Wilton - it will apply.

Deciding what standard applies is a "thorny question" federal courts have taken vastly different approaches. ${ }^{9}$. The eight circuits that have answered this question are hopelessly divided, having offered four distinct approaches. Four circuits ${ }^{10}$ have held that courts have little

6. Nondeclaratory relief includes any type of relief other than a declaratory judgment, most commonly money damages or an injunction.

7. Colo. River Water Conservation Dist. v. United States, 424 U.S. 800, 813 (1976) (quoting Cty. of Allegheny v. Frank Mashuda Co., 360 U.S. 185, 188-89 (1959)).

8. Lexington Ins. Co. v. Rolison, 434 F. Supp. 2d 1228, 1236 (S.D. Ala. 2006).

9. See, e.g., State Farm Mut. Auto. Ins. Co. v. Physicians Grp. of Sarasota, L.L.C., 9 F. Supp. 3d 1303, 1308 (M.D. Fla. 2014) ("Circuits are split as to whether the Brillhart doctrine can be applied when a plaintiff requests mixed forms of relief including a declaratory judgment ...."); Mass. Biologic Labs. of the Univ. of Mass. v. MedImmune, LLC, 871 F. Supp. 2d 29, 33-35 (D. Mass. 2012) (surveying this circuit split); Circuit Review Staff, Current Circuit Splits, 6 SETON Hall CiRCUIT REV. 135, 144 (2009) (recognizing the further circuit split over the application of abstention doctrines to mixed complaints caused by R.R. Street \& Co. v. Vulcan Materials Co., 569 F.3d 711 (7th Cir. 2009)).

Courts often refer to Brillhart/Wilton as a type of abstention doctrine, but as the Seventh Circuit has astutely observed, that term is not necessarily the best description of the doctrine. Typically, abstention "refers to a group of judicially-created doctrines. The decision to stay an action under the Declaratory Judgment Act does not require the court to reach for a judiciallycreated abstention doctrine. Rather, the Act itself provides the district court with the necessary discretion." Med. Assurance Co. v. Hellman, 610 F.3d 371, 378 (7th Cir. 2010). Nevertheless, this Article does not concern itself with any definitional disputes, as any such disputes are irrelevant in this Article's focus on a particular question on the relationship between Brillhart/Wilton and various abstention doctrines.

10. See vonRosenberg v. Lawrence, 781 F.3d 731, 735-36 (4th Cir. 2015); Vill. of Westfield v. Welch's, 170 F.3d 116, 120 (2d Cir. 1999); Southwind Aviation, Inc. v. Bergen Aviation, Inc., 23 F.3d 948, 950-51 (5th Cir. 1994); Sinclair Oil Corp. v. Amoco Prod. Co., 982 F.2d 437, 440-41 (10th Cir. 1992).

The Fourth Circuit recently adopted this position. See vonRosenberg, 781 F.3d at 735-36. Arguably, the presence of claims subject to exclusive federal jurisdiction impacted the court's analysis in that case, although the court did not expressly state that those claims influenced its reasoning. Thus, this Article assumes that the claims for nondeclaratory relief that were required to be brought in federal court were not essential to the Fourth Circuit's holding. See infra note 163 and 
discretion to abstain in these cases, as they must apply Colorado River's "exceptional circumstances" doctrine to the entire case. Two circuits ${ }^{11}$ have directed district courts to determine whether the claims for nondeclaratory relief are jurisdictionally independent of the claims for declaratory relief, and if those claims for nondeclaratory relief are independent, then the Colorado River doctrine applies. Third, one circuit $^{12}$ has instructed district courts to look to the heart of the complaint, and if the complaint at its core seeks declaratory relief, then Brillhart/Wilton applies. And finally, one circuit ${ }^{13}$ has taken the view that the claims should be disentangled, with the claims for nondeclaratory relief being subject to Colorado River and the claims for declaratory relief being evaluated under Brillhart/Wilton. Given these conflicting approaches, one district court has commented that this question offers "no simple compromise" because "[t]here is no resounding majority view.","

These four approaches represent starkly different answers to the question of abstention and mixed complaints. They are not, however, equally satisfactory answers. Of these approaches, the heart of the complaint approach is superior because it best balances four important considerations: first, preserving the unique language in the Declaratory Judgment Act; second, promoting the wise use of judicial resources; third, preventing parties from manipulating litigation; and fourth, providing courts the needed flexibility for reaching the correct result.

Beyond the intellectually engaging questions presented, this circuit split raises an important and timely issue for the practice of law. As Americans become more litigious generally, ${ }^{15}$ more complaints will be filed, and as lawyers get more creative in pleading cases, courts are more likely to see complaints that involve claims for both declaratory and nondeclaratory relief. Despite this circuit split, scholars have given virtually no attention to this issue. ${ }^{16}$ In fact, some legal scholarship even

accompanying text.

11. R.R. Street \& Co., 569 F.3d at 716; United Nat'l Ins. Co. v. R\&D Latex Corp., 242 F.3d 1102, 1113 (9th Cir. 2001).

12. Royal Indem. Co. v. Apex Oil Co., 511 F.3d 788, 793-94 (8th Cir. 2008).

13. Rossi v. Gemma, 489 F.3d 26, 34-38 (1st Cir. 2007).

14. Columbia Gas of Pa. v. Am. Int'l Grp., No. 10-1131, 2011 WL 294520, at *1 (W.D. Pa. Jan. 27, 2011).

15. See Wm. Grayson Lambert, Toward A Better Understanding of Ripeness and Free Speech Claims, 65 S.C. L. REV. 411, 412 n.3 (2013) (collecting sources discussing rising caseloads).

16. The only scholarship that addresses this issue directly is Tyler A. Mamone, Comment, No Simple Compromise: Reconciling Duty and Discretion Under Colorado River Abstention in Claims 
seems unaware of the circuit split. ${ }^{17}$ Notwithstanding the lack of meaningful attention from legal scholars, as these cases become more common, the more likely the Supreme Court is to grant certiorari on this issue. The resolution to the circuit split offered in this Article provides a suggested approach for the Court when it confronts this issue and for lower courts until the Supreme Court resolves the circuit split. ${ }^{18}$

This Article proceeds in three parts. Part I sets out the Brillhart/Wilton doctrine, beginning with the adoption of the Declaratory Judgment Act and continuing through the Supreme Court's decisions in Brillhart in 1942 and in Wilton over half a century later. Part II then presents the circuit split that has developed over what abstention rules apply to mixed complaints. Finally, Part III explains why the heart of the complaint rule is the best approach.

\section{THE DECLARATORY JUDGMENT ACT AND THE BRILLHART/WILTON \\ DOCTRINE}

This Part sets the foundation for examining how the Brillhart/Wilton doctrine applies to mixed complaints. It first discusses the Declaratory Judgment Act, describing its adoption and its language before then examining in depth Brillhart v. Excess Insurance Co., the circuit split that developed after the Court decided Colorado River Water Conservation District v. United States, ${ }^{19}$ and the Supreme Court's resolution of that circuit split in Wilton v. Seven Falls Co.

\section{A. The Declaratory Judgment Act}

As early as 1918, scholars such as Professor Edwin Borchard at Yale Law School advocated for the adoption of declaratory judgments as a potential remedy "to afford security and relief against uncertainty and

for Mixed Relief, 45 U. ToL. L. REv. 347 (2014). As discussed later in this Article, the proposal in that article does not offer the best solution to the circuit split.

17. See, e.g., Mathew D. Staver, The Abstention Doctrines: Balancing Comity with Federal Court Intervention, 28 SETON HALL L. REv. 1102, 1152 (1998) (stating simply that Brillhart/Wilton was inapplicable because the plaintiff in a case also sought declaratory relief, with no recognition that federal courts of appeal are sharply divided on this issue).

18. This Article does not attempt to survey all cases in which these various approaches have been applied. Indeed, I have no need to do so, as that task has already been aptly accomplished. See generally Eric C. Surette, Propriety and Extent of Application of Brillhart/Wilton Abstention Doctrine to "Mixed Claims" Involving Both Declaratory and Coercive Relief, 66 A.L.R. Fed. 2d 467 (2012).

19. Colo. River Water Conservation Dist. v. United States, 424 U.S. 800 (1976). 
doubt." ${ }^{20}$ The American Bar Association called a bill proposed in Congress that would introduce declaratory judgments into the federal courts " $[t]$ he most important legislation of the year affecting the administration of justice." ${ }^{21}$ Although other legal systems had a remedy similar to a declaratory judgment, ${ }^{22}$ Congress did not move quickly to adopt the declaratory judgment, ${ }^{23}$ even after the American Bar Association and the National Conference Commissioners on Uniform State Laws published the Uniform Declaratory Judgment Act in 1922. ${ }^{24}$ Congress held hearings during the 1920 s on bills that would have allowed federal courts to grant declaratory judgments, but none of these hearings resulted in the passage of a bill permitting federal courts to grant such relief. ${ }^{25}$ Moreover, while Congress was debating these bills, the Supreme Court decided three cases that cast doubt on the constitutionality of declaratory judgments. ${ }^{26}$

In 1933, however, the Supreme Court reversed course in Nashville,

20. Edwin M. Borchard, The Declaratory Judgment-A Needed Procedural Reform, 28 YALE L.J. 1, 4 (1918); see also Edwin M. Borchard, The Declaratory Judgment-A Needed Procedural Reform II, 28 YALE L.J. 105, 109 (1918); Edson R. Sunderland, The Courts as Authorized Legal Advisors of the People, 54 AM. L. REv. 161, 174 (1920); Edson R. Sunderland, A Modern Evolution in Remedial Rights-The Declaratory Judgment, 16 MicH. L. REV. 69, 70 (1917).

21. 42 ANN. REP. A.B.A. 277, 284 (1919).

22. European nations had something akin to declaratory judgments in the early twentieth century, and England and Germany had something similar as far back as medieval times. See Borchard, The Declaratory Judgment-A Needed Procedural Reform, supra note 20, at 14-29. The declaratory judgment goes back even further than the middle ages, however, as it can be traced back to ancient Rome. See id. at 12-14; see also Donald L. Doernberg \& Michael B. Mushlin, The Trojan Horse: How the Declaratory Judgment Act Created a Cause of Action and Expanded Federal Jurisdiction While the Supreme Court Wasn't Looking, 36 UCLA L. REV. 529, 550 n.90 (1989).

23. See Lisa A. Dolak, Power or Prudence: Toward A Better Standard for Evaluating Patent Litigants' Access to the Declaratory Judgment Remedy, 41 U.S.F. L. REV. 407, 408 n.6 (2007) (“[A] bill proposing a federal declaratory judgment remedy had been introduced in every Congressional session from 1919 to $1932 \ldots$. ...).

24. Med. Assurance Co. v. Hellman, 610 F.3d 371, 377 (7th Cir. 2010) (citing Uniform Declaratory Judgments Act, $\S \S 1$ et seq.).

25. See Dolak, supra note 23, at 408 n.6 (providing citations to examples of the statements from various hearings during the 1920s). One of the more colorful descriptions of the need for declaratory judgments came from Representative Ralph Waldo Emerson Gilbert of Kentucky, who said, "Under the present law you take a step in the dark and then turn on the light to see if you stepped into a hole. Under the declaratory law you turn on the light and then take the step." 69 CONG. REC. 2030 (1928) (remarks of Rep. Gilbert).

26. See Willing v. Chi. Auditorium Ass'n, 277 U.S. 274, 289 (1928) (observing that a declaratory judgment claim "is not a case or controversy within the meaning of article 3 of the Constitution”); Liberty Warehouse Co. v. Burley Tobacco Growers' Co-op. Mktg. Ass'n, 276 U.S. 71, 89 (1928) ("This court has no jurisdiction to review a mere declaratory judgment."); Liberty Warehouse Co. v. Grannis, 273 U.S. 70, 76 (1927) (holding that a state declaratory judgment law "neither purports to nor can extend the jurisdiction of the district courts beyond the constitutional limitations"); see also Doernberg \& Mushlin, supra note 22, at 558-61 (discussing these decisions). 
Chattanooga \& St. Louis Railway v. Wallace ${ }^{27}$ and upheld Tennessee's declaratory judgment law, explaining that "the Constitution does not require that the case or controversy should be presented by traditional forms of procedure, invoking only traditional remedies. The judiciary clause of the Constitution defined and limited judicial power, not the particular method by which that power might be invoked." 28 With that decision, the Court "cleared the way for passage of the federal [Declaratory Judgment] Act.",29

Congress moved quickly after Wallace and passed the Declaratory Judgment $\mathrm{Act}^{30}$ in 1934. The Act provides, in relevant part,

In a case of actual controversy within its jurisdiction ... any court of the United States, upon the filing of an appropriate pleading, may declare the rights and other legal relations of any interested party seeking such declaration, whether or not further relief is or could be sought. Any such declaration shall have the force and effect of a final judgment or decree and shall be reviewable as such. ${ }^{31}$

A few years later in 1937, the Court upheld the constitutionality of the Act, observing that the Act limited declaratory judgments to cases in which a case or controversy existed under Article III $^{32}$ and did not expand federal jurisdiction beyond that constitutional limit. ${ }^{33}$ Not until

27. Nashville, Chattanooga \& St. Louis Ry. v. Wallace, 288 U.S. 249 (1933).

28. Id. at 264 .

29. Doernberg \& Mushlin, supra note 22, at 569; see also Raymond W. Beauchamp, Note, England's Chilling Forecast: The Case for Granting Declaratory Relief to Prevent English Defamation Actions from Chilling American Speech, 74 FORDHAM L. REV. 3073, 3092-93 (2006) (discussing Wallace and its impact); Andrew Bradt, "Much to Gain and Nothing to Lose" Implications of the History of the Declaratory Judgment for the (B)(2) Class Action, 58 ARK. L. REV. 767, 779-80 (2006) (same).

30. Act of June 14, 1934, ch. 512, 48 Stat. 955. See Doernberg \& Mushlin, supra note 22 at 561 n.150. Congress left virtually no legislative record in passing the Act. See Dolak, supra note 23, at 408 n.6 ("The legislative history from the 1934 Congressional session is very limited because there were no debates in either the House or the Senate on the bill that year." (citing 78 Cong. Rec. 10,564-65, 10,919 (1934); 78 Cong. Rec. 8224 (1934))); see also Doernberg \& Mushlin, supra note 22 , at 561. Scholars thus look to the hearings and debates on earlier bills that would have permitted federal courts to grant declaratory judgments for insight on Congress's intentions in passing the Declaratory Judgment Act. See Dolak, supra note 23, at 408 n.6; see also Doernberg \& Mushlin, supra note 22 , at 561-68.

31. 28 U.S.C. $\$ 2201$ (a) (2012) (emphasis added). The Act excludes certain types of cases, including how organizations are classified by the Internal Revenue Service and cases involving tax liability in bankruptcy. Id.

32. See U.S. CONST. art. III, § 2 .

33. See Aetna Life Ins. Co. v. Haworth, 300 U.S. 227, 239-40 (1937); see also Medtronic, Inc. v. Mirowski Family Ventures, LLC, 134 S. Ct. 843, 848 (2014) (“[T]he Declaratory Judgment Act does not 'extend' the 'jurisdiction' of the federal courts." (quoting Skelly Oil Co. v. Phillips 
five years later in Brillhart, however, did the Court fully explain district courts' obligations and discretion under the Act.

\section{B. Brillhart v. Excess Insurance Co.}

Litigants had enjoyed the benefits of the Declaratory Judgment Act for less than a decade when the Supreme Court decided Brillhart v. Excess Insurance Co. in 1942. In this case, Excess Insurance Co. had entered into a reinsurance agreement with Central Mutual Insurance Co. in 1932. ${ }^{34}$ Two years later, Central had issued a liability policy to Cooper-Jarrett, Inc., and then later that year in October, a truck driven by a Cooper-Jarrett employee caused an accident that resulted in the death of Brillhart's decedent. ${ }^{35}$ Brillhart sued in state court in Missouri, and Cooper-Jarrett sought to have Central defend the case. ${ }^{36}$ Central refused, however, claiming that the accident was not covered under the policy, so Cooper-Jarrett hired its own attorney. ${ }^{37}$

During the litigation in the Missouri court, both Central and CooperJarrett experienced major financial problems. Central became insolvent and was liquidated by an Illinois court, which entered an order prohibiting any claimant from prosecuting a claim against Central. ${ }^{38}$ After Central went into this receivership, Cooper-Jarrett filed for bankruptcy. ${ }^{39}$ The court overseeing the bankruptcy allowed Brillhart to withdraw his claims in the bankruptcy action and pursue his lawsuit against Cooper-Jarrett, on the ground that Cooper-Jarrett had insurance. ${ }^{40}$ As Brillhart pursued his claim, Cooper-Jarrett's attorney withdrew, and the company never hired another lawyer to represent it, ultimately resulting in a default judgment of $\$ 20,000$ against it. ${ }^{41}$ Based on this

Petroleum Co., 339 U.S. 667, 671 (1950))). Despite this “procedural only" view of the Act, some scholars have argued that Congress actually did intend to expand federal jurisdiction and that the Court has actually permitted jurisdiction to be expanded under the Act. See generally Doernberg \& Mushlin, supra note 22.

34. Excess Ins. Co. of Am. v. Brillhart, 121 F.2d 776, 777 (10th Cir. 1941) rev'd, Brillhart v. Excess Ins. Co. of Am., 316 U.S. 491 (1942). I primarily use the Tenth Circuit's opinion to describe the facts of this case because that opinion sets forth a more detailed factual background than the Supreme Court's opinion.

35. Id.

36. Id.

37. Id.

38. Id.

39. Id.

40. Id.

41. Brillhart v. Excess Ins. Co. of Am., 316 U.S. 491, 492 (1942); Excess Ins. Co. of Am., 121 F.2d at 777 . 
judgment, Brillhart filed a garnishment proceeding against Central in Missouri state court, despite the order of the Illinois court, and judgment was entered for Brillhart in this case. ${ }^{42}$

Excess first learned of this dispute between Brillhart and CooperJarrett when Cooper-Jarrett's attorney in the bankruptcy proceeding contacted Excess in 1939 about its reinsurance agreement with Central. ${ }^{43}$ Excess, before it was ever sued in state court, filed a declaratory judgment action in federal court in Kansas, seeking a declaration that it was not liable for the judgment against Central because Central had failed to notify Excess of the pending litigation, as the reinsurance agreement required Central to do. ${ }^{44}$ The district court dismissed the case "because of a reluctance to prolong the litigation." 45

The Tenth Circuit reversed. Although noting that courts have "some discretionary power" over whether to hear cases "[w]here a prior action has been filed in a court of concurrent jurisdiction between the same parties and involving the same issues," the district court had no such authority to dismiss this case. ${ }^{46}$ The circuit court noted that this case "was squarely within the purview" of the Declaratory Judgment Act, which was designed "to afford one who is threatened with liability an early opportunity to determine his rights by forcing his adversary to come into court and assert his claim, without waiting until it pleased [the adversary] to institute an action to recover." party to the garnishment proceeding, the only pending state court action. ${ }^{48}$ The Tenth Circuit remanded the case for the district court to decide Excess's claim on the merits. ${ }^{49}$

Brillhart appealed, and the Supreme Court granted certiorari. ${ }^{50}$ In an opinion by Justice Frankfurter, the Court focused on what obligation federal district courts have to hear cases brought under the Declaratory

\footnotetext{
42. Excess Ins. Co. of Am., 121 F.2d at 777.

43. Id.

44. Brillhart, 316 U.S. at 493.

45. Id. at 493-94; see also id. at 494 n.1 (quoting the district court as saying, "Well, I don't think that this court will interfere with [the state court proceedings]. The case will be dismissed.... [T] his court feels in its discretion that it ought not to interfere with that [state court] litigation in any way.").

46. Excess Ins. Co. of Am., 121 F.2d at 778

47. Id.

48. $I d$.

49. Id.

50. Brillhart v. Excess Ins. Co. of Am., 314 U.S. 606 (1942).
} 
Judgment Act. ${ }^{51}$ The Court explained that when a plaintiff files a declaratory judgment action, a district court is "under no compulsion to exercise that jurisdiction" granted by the Act. ${ }^{52}$ That "another proceeding was pending in a state court in which all the matters in controversy between the parties could [have] be[en] fully adjudicated" was "relevant" to determining whether a district court should exercise jurisdiction over the claim for declaratory relief because "[o]rdinarily it would be uneconomical as well as vexatious for a federal court to proceed in a declaratory judgment suit where another suit is pending in a state court presenting the same issues, not governed by federal law, between the same parties." 53

Based on this rationale, the Court instructed that in instances such as this case, district courts "should ascertain whether the questions in controversy between the parties to the federal suit, and which are not foreclosed under the applicable substantive law, can better be settled in the proceeding pending in the state court." ${ }^{, 54}$ In conducting this inquiry, district courts should consider

the scope of the pending state court proceeding and the nature of defenses open there[,].... whether the claims of all parties in interest can satisfactorily be adjudicated in that proceeding, whether necessary parties have been joined, [and] whether such parties are amenable to process in that proceeding....

District courts should also consider any other factors that may be relevant to whether they should exercise jurisdiction over a declaratory judgment action. ${ }^{56}$

Applying this standard, the Court held that the district court abused its discretion because the district court did not consider whether Excess's claims were foreclosed under Missouri law or could be considered by the state court in the garnishment proceeding. ${ }^{57}$ Rather than "attempt[ing] to pronounce independently upon Missouri law," the Court remanded the case to the district court to consider these issues in determining whether

51. See Brillhart v. Excess Ins. Co. of Am., 316 U.S. 491, $493-95$ (1942).

52. Id. at 494 .

53. Id. at 495; see also id. ("Gratuitous interference with the orderly and comprehensive disposition of a state court litigation should be avoided.").

54. Id.

55. Id.

56. See id. ("We do not now attempt a comprehensive enumeration of what in other cases may be revealed as relevant factors governing the exercise of a district court's discretion.").

57. Id. at 495-97. 
to exercise jurisdiction. ${ }^{58}$

The standard that the Court adopted in Brillhart provides "[district] courts great freedom in deciding whether to entertain declaratory judgment actions." ${ }^{, 59}$ By not limiting the relevant factors that district courts can consider when determining whether to exercise jurisdiction, the Court recognized that district judges have their "boots on the ground" to examine carefully the facts of each case. ${ }^{60}$ This broad discretion permitted by Brillhart allows district courts to make their decisions on a case-by-case basis, giving them a necessary degree of flexibility to reach a just result in each case. ${ }^{61}$ Additionally, this discretion represented an exception to the general rule that a federal court "could not abdicate its authority or duty in favor of the state [court's] jurisdiction." ${ }^{\text {"62 }}$ Finally, this standard recognizes that state courts are as competent as any federal court to resolve the legal issues before them. ${ }^{63}$

58. Id. at 497-98.

Chief Justice Stone dissented. He argued that "the question whether [Excess] can litigate its present cause of action in the statutory garnishment proceeding in Missouri is at best not free from doubt," as the Missouri Supreme Court had not opined on this question. Id. at 500-01 (Stone, C.J., dissenting). Believing that a district court "plainly [has] its duty to hear and decide all the issues necessary for disposition of the case unless it was made to appear with reasonable certainty that the issues could be adjudicated in [a state court proceeding]," the Chief Justice argued that Excess "ought not to be penalized" for invoking federal jurisdiction here to have its claims answered. Id. at 500, 502 (emphasis added).

In his concurring opinion, Justice Douglas focused on Chief Justice Stone's dissent about whether Excess was already bound under Missouri law to pay the damages owed to Brillhart, arguing that the Chief Justice focused too narrowly on whether Excess's claims could be litigated in Missouri court, without considering whether these claims "had been 'previously foreclosed' under Missouri law." See id. at 498 (Douglas, J., concurring).

59. Grace M. Giesel, The Expanded Discretion of Lower Courts to Regulate Access to the Federal Courts After Wilton v. Seven Falls Co.: Declaratory Judgment Actions and Implications Far Beyond, 33 Hous. L. Rev. 393, 405 (1996).

60. United States v. Van Nguyen, 602 F.3d 886, 896 (8th Cir. 2010) (internal citation omitted).

61. See Recent Case, Declaratory Judgments-Granting of Declaratory Judgment on Issues Involved in Pending Criminal Prosecution in Justice of Peace Court Held Not Abuse of Discretion, 59 HARV. L. REV. 1311, 1312-13 (1946) (discussing various approaches to when a court should refuse to grant a declaratory judgment and concluding that "the better practice is to examine each individual case and openly weigh the factors creating a need for declaratory relief against the general reasons for denying it").

62. Kline v. Burke Constr. Co., 260 U.S. 226, 234 (1922); see also Note, Power to Stay Federal Proceedings Pending Termination of Concurrent State Litigation, 59 YALE L.J. 978, 980-81 (1950).

63. See Giesel, supra note 59, at 405 ("[Brillhart] implicitly, if not explicitly, represented a view that state courts are capable and fair arbiters of legal issues."); see also Cousins v. Wigoda, 463 F.2d 603, 607 (7th Cir. 1972) ("[W]e must assume that [a state] court would properly determine the merits of any federal issue properly presented to it."); Ann Althouse, Federalism, Untamed, 47 VAND. L. REV. 1207, 1209 (1994) (arguing that the Supreme Court's shaping of jurisdictional rules "defeat[s] the notion that federal courts must address all questions of federal rights"). 
After the Court decided Brillhart, lower federal courts used the discretion they were given in deciding whether to exercise jurisdiction in declaratory judgment claims. For instance, in Southern California Petroleum Corp. v. Harper ${ }^{64}$ the Fifth Circuit upheld a district court's decision not to exercise jurisdiction. In this case, Harper, a landowner in Texas, had a dispute with Southern California Petroleum over oil and gas leases on his land. ${ }^{65}$ In 1955, Harper sued Southern California Petroleum in federal court, alleging that the lease had not been properly developed and that wells had not been properly operated, but he lost this suit. ${ }^{66}$ In 1958, Harper sued Southern California Petroleum Corp. again on similar theories, this time based specifically on a waterflood program begun earlier that year, which Harper claimed would destroy the value of his land. ${ }^{67}$ Southern California Petroleum and a codefendant removed the case to federal court and filed a complaint of their own, seeking to remove an alleged cloud on their title and a declaratory judgment relating to the development of the leases. ${ }^{68}$ The district court remanded Harper's case back to state court for lack of diversity and dismissed Southern California Petroleum's claims, refusing to grant declaratory relief because those issues were the same as the issues in Harper's pending state court case. ${ }^{69}$ Writing for the Fifth Circuit, Judge John Minor Wisdom cited Brillhart before noting, "[t]he policy against federal interference with a state suit previously filed is of long standing and is a necessary objective in maintaining a balanced federal-state

This view underlies Justice Story's decision in Martin v. Hunter's Lessee, 14 U.S. 304, 315 (1816), when he wrote that lower federal courts "may not exist [unless Congress chooses to create them]; and, therefore, the appellate jurisdiction must extend beyond appeals from the courts of the United States only. The state courts are to adjudicate under the supreme law of the land, as a rule binding upon them."

Even before the Supreme Court decided Brillhart and provided guidance for when courts can refuse to hear claims for declaratory relief, some courts had recognized the limits on how litigants could use declaratory judgments. See, e.g., Am. Auto. Ins. Co. v. Freundt, 103 F.2d 613, 617 (7th Cir. 1939) ("The wholesome purposes of declaratory acts would be aborted by its use as an instrument of procedural fencing either to secure delay or to choose a forum. It was not intended by the act to enable a party to obtain a change of tribunal and thus accomplish in a particular case what could not be accomplished under the removal act, and such would be the result in the instant case."). For these courts, Brillhart simply affirmed the approach that they had adopted.

64. S. Cal. Petrol. Corp. v. Harper, 273 F.2d 715 (5th Cir. 1960).

65. Id. at 716 .

66. Id. at 716-17.

67. Id. at 717 .

68. Id.

69. Id. at $717-18$. 
relationship."70 Given this policy, the court of appeals held that the district court was within its discretion in dismissing the claims for declaratory relief.

Of course, although courts of appeals frequently cited Brillhart's standard for not deciding claims for declaratory relief, they did not simply rubberstamp district courts' decisions not to grant that relief. For example, in Franklin Life Insurance Co. v. Johnson, ${ }^{71}$ the Tenth Circuit explained, "[T]he trial court is vested with rather wide discretion in determining whether or not it will exercise existing jurisdiction .... But it is a judicial discretion, subject to review, and must be exercised in accordance with legal principles." 72 In this case, Franklin Life Insurance Co. had sought a declaratory judgment that it was not liable under a life insurance policy because the decedent's death was caused by a selfinflicted gunshot wound. ${ }^{73}$ The decedent's wife, Johnson, however, filed suit in Colorado state court, seeking benefits under the policy, which led the district court to dismiss Franklin Life's claim for declaratory relief. ${ }^{74}$ Considering the "practical considerations affecting the interrelation of courts exercising coordinate and concurrent jurisdiction," 75 the Tenth Circuit reasoned that the district court had no basis for not hearing the declaratory judgment claim because the state court case was filed two months after the case began in federal court, ${ }^{76}$ and the state court case did not include all relevant parties. $^{77}$

\section{Wilton v. Seven Falls Co.}

For decades, Brillhart provided clear guidance for lower federal courts having to decide whether to decide claims for declaratory relief.

70. Id. at 720; see also Shell Oil Co. v. Frusetta, 290 F.2d 689, 691-92 (9th Cir. 1961) (holding that a district court did not abuse its discretion in declining to hear a claim for declaratory relief when a litigant tried to accomplish through the Declaratory Judgment Act what it could not achieve under the removal statutes).

71. Franklin Life Ins. Co. v. Johnson, 157 F.2d 653 (10th Cir. 1946).

72. Id. at 656 .

73. Id. at 655 .

74. Id. at 656 .

75. Id.

76. Id. at 657 .

77. Id. at 658. The policy named Cora Johnson as the primary beneficiary and Helen Johnson as the contingent beneficiary, who would receive benefits only after Cora Johnson died and some value of the policy remained unpaid. Id; see also Am. Cas. Co. of Reading v. Howard, 173 F.2d 924, 928 (4th Cir. 1949) (holding that the district court abused its discretion by not hearing a claim for declaratory relief because the case would clarify unsettled legal issues and provide relief from uncertainty for the parties). 
The situation became more complicated, however, after the Supreme Court decided Colorado River Water Conservation District v. United States in 1976.

\section{Colorado River and the Subsequent Confusion.}

The federal government, pursuant to 28 U.S.C. $\S 1345,{ }^{78}$ sued approximately 1,000 water users in Colorado, seeking a declaration of the United States' rights to that water. ${ }^{79}$ Shortly after this suit was filed, one of the defendants joined the United States in ongoing proceedings in state court, using the McCarran Amendment ${ }^{80}$ to bring the United States into that action. ${ }^{81}$ The district court abstained from deciding the case filed by the United States under $\S 1345$ in deference to the state court proceedings. $^{82}$

Beginning its analysis, the Supreme Court laid forth a seemingly simple proposition: "[a]bstention from the exercise of federal jurisdiction is the exception, not the rule." 83 The Court walked through its various abstention doctrines, including when a constitutional question can be avoided, ${ }^{84}$ when a case presents difficult questions of state law bearing on important public policy issues, ${ }^{85}$ and when federal jurisdiction has been invoked to thwart state criminal proceedings (absent bad faith from

78. 28 U.S.C. $\$ 1345$ (2012) ("Except as otherwise provided by Act of Congress, the district courts shall have original jurisdiction of all civil actions, suits or proceedings commenced by the United States, or by any agency or officer thereof expressly authorized to sue by Act of Congress.").

79. Colo. River Water Conservation Dist. v. United States, 424 U.S. 800, 805 (1976).

80. 43 U.S.C. $\$ 666(a)$ (2012) ("Consent is given to join the United States as a defendant in any suit (1) for the adjudication of rights to the use of water of a river system or other source, or (2) for the administration of such rights, where it appears that the United States is the owner of or is in the process of acquiring water rights by appropriation under State law, by purchase, by exchange, or otherwise, and the United States is a necessary party to such suit.").

81. Colo. River Water Conservation Dist., 424 U.S. at 806.

82. Id.

83. Id. at 813 .

84. See R.R. Comm'n of Tex. v. Pullman Co., 312 U.S. 496, 499 (1941). See generally Martha A. Field, Abstention in Constitutional Cases: The Scope of the Pullman Abstention Doctrine, $122 \mathrm{U}$. PA. L. REV. 1071 (1974) (discussing Pullman abstention and its operation).

85. See La. Power \& Light Co. v. City of Thibodaux, 360 U.S. 25, 28-29 (1959); Burford v. Sun Oil Co., 319 U.S. 315, 333-34 (1943). Although these cases do not address exactly the same issue, the Supreme Court in Colorado River treated them as the same type of abstention, a characterization that scholars have also recognized. Compare Colo. River Water Conservation Dist., 424 U.S. at 814-15, with 17A Charles Alan Wright \& ARTHur R. Miller, Federal PracticE AND PROCEDURE $\S 4245$ (3d ed. 2004). On the Burford doctrine's development, see generally Gordon G. Young, Federal Court Abstention and State Administrative Law from Burford to Ankenbrandt: Fifty Years of Judicial Federalism Under Burford v. Sun Oil Co. and Kindred Doctrines, 42 DEPAUL L. REV. 859 (1993). 
or harassment by state officials), ${ }^{86}$ ultimately concluding that this case did not fit within any of these categories. ${ }^{87}$ Based on

the virtually unflagging obligation of the federal courts to exercise the jurisdiction given them. ... and the absence of weightier considerations of constitutional adjudication and state-federal relations, the circumstances permitting the dismissal of a federal suit due to the presence of a concurrent state proceeding for reasons of wise judicial administration are considerably more limited than the circumstances appropriate for abstention. 8

Such factors to consider include which court had jurisdiction over a case first, the inconvenience of the federal forum, and the desirability of avoiding piecemeal litigation, with "[o]nly the clearest of justifications ... warrant[ing] dismissal." ${ }^{, 89}$

Here, the Court held that the district court properly dismissed the suit because the McCarran Amendment reflected the desire to have waterrights issues decided in a single proceeding, the lack of substantial proceedings in the district court, and the involvement of so many statelaw water rights with 1,000 defendants. ${ }^{90}$

Colorado River reflected Chief Justice Marshall's language in Cohens v. Virginia ${ }^{91}$ in 1821, when he wrote that federal courts have "no ... right to decline the exercise of jurisdiction which is given." 92 Almost immediately after the Court decided Colorado River, scholars

86. Younger v. Harris, 401 U.S. 37, 53-54 (1971). See generally George D. Brown, When Federalism and Separation of Powers Collide-Rethinking Younger Abstention, 59 GEO. WASH. L. REV. 114 (1990) (discussing the tension between federalism and separation of powers in Younger and predicting that this tension will lead to a rethinking of the doctrine based on the policies that undergird it).

87. Colo. River Water Conservation Dist., 424 U.S. at 814-17.

88. Id. at $817-18$.

89. Id. at 819 .

90. Id. at 820. This decision affirmed the district court's decision, but it reversed the Tenth Circuit's decision, which had held that the district court erred in not deciding the case. Id. at 821 . For a concise summary and analysis of Colorado River, see James C. Rehnquist, Taking Comity Seriously: How to Neutralize the Abstention Doctrine, 46 STAN. L. REV. 1049, 1092-95 (1994).

91. Cohens v. Virginia, 19 U.S. 264 (1821).

92. Id. at 404; see also England v. La. State Bd. of Med. Exam'rs, 375 U.S. 411, 415 (1964) ("There are fundamental objections to any conclusion that a litigant who has properly invoked the jurisdiction of a Federal District Court to consider federal constitutional claims can be compelled, without his consent and through no fault of his own, to accept instead a state court's determination of those claims."); Willcox v. Consol. Gas Co. of N.Y., 212 U.S. 19, 40 (1909) ("When a Federal court is properly appealed to in a case over which it has by law jurisdiction, it is its duty to take such jurisdiction ...."); David A. Sonenshein, Abstention: The Crooked Course of Colorado River, 59 Tul. L. REV. 651, 652-64 (1985) (discussing how Colorado River fits with Supreme Court precedent and other abstention doctrines). 
recognized its potential impact on abstention doctrines, ${ }^{93}$ and courts recognized the tension between Colorado River and Brillhart. ${ }^{94}$

Unsurprisingly, this tension resulted in a circuit split. Some circuits, such as the Second ${ }^{95}$ and Eighth, ${ }^{96}$ held that Colorado River's "exceptional circumstances" test applied to district courts' determination of whether to hear a claim for declaratory relief. Other circuits, however, such as the Fourth $^{97}$ and Fifth, ${ }^{98}$ continued to treat Brillhart as the standard in cases involving declaratory relief.

\section{Clarifying the Confusion}

After the circuit split developed about whether Brillhart or Colorado River applied to decisions not to exercise jurisdiction over claims for declaratory relief, the Supreme Court took up Wilton v. Seven Falls Co. to resolve the division among the lower courts.

Wilton started in 1992 with a dispute over oil and gas leases in Texas that was destined for litigation. ${ }^{99}$ One party to that dispute, the Hill

93. See generally Michael M. Wilson, Comment, Federal Court Stays and Dismissals in Deference to Parallel State Court Proceedings: The Impact of Colorado River, 44 U. CHI. L. REV. 641 (1977). Although Colorado River is often considered an abstention doctrine of its own, courts and scholars do not necessarily agree on this terminology. See Calvin R. Massey, Abstention and the Constitutional Limits of the Judicial Power of the United States, 1991 BYU L. REV. 811, 833 \& nn.104-06 (1991) (discussing how courts and scholars characterize Colorado River).

94. See, e.g., Transamerica Occidental Life Ins. Co. v. DiGregorio, 811 F.2d 1249, 1254 \& n.4 (9th Cir. 1987); Fuller Co. v. Ramon I. Gil, Inc., 782 F.2d 306, 308-11 (1st Cir. 1986); Calvert Fire Ins. Co. v. Am. Mut. Reinsurance Co., 600 F.2d 1228, 1233-34 (7th Cir. 1979).

Even the Supreme Court was not quite clear on the relationship of Colorado River and Brillhart and the applicable standard for when a district court may decline to exercise jurisdiction. In Will v. Calvert Fire Insurance Co., a plurality of the Court held that "the pendency of an action in the state court is no bar to proceedings concerning the same matter in the Federal court having jurisdiction," even if the district court was "under no compulsion to exercise that jurisdiction." Will v. Calvert Fire Ins. Co., 437 U.S. 655, 662 (1978) (citations omitted). The plurality cited Brillhart for support here, stating that Colorado River had not undermined that earlier decision. Id. at 664 . Justice Blackmun, who concurred in the judgment, disagreed with this interpretation of Colorado River, believing that the Court may have cut back on Brillhart. Id. at 667-68 (Blackmun, J., concurring in the judgment). In dissent, Justice Brennan, joined by Chief Justice Burger and Justices Marshall and Powell, believed that Brillhart was not the appropriate standard, but instead Colorado River was, albeit because of the nature of the claims in Will, which did not ask for a declaratory judgment. Id. at 671-72 (Brennan, J., dissenting).

95. See Lumbermens Mut. Cas. Co. v. Conn. Bank \& Tr. Co., 806 F.2d 411, 412 (2d Cir. 1986).

96. See Emp'rs Ins. of Wausau v. Mo. Elec. Works, Inc., 23 F.3d 1372, 1374-75 (8th Cir. 1994).

97. See Mitcheson v. Harris, 955 F.2d 235, 237-38 (4th Cir. 1992).

98. See Travelers Ins. Co. v. La. Farm Bureau Fed'n, 996 F.2d 774, 778 n.12 (5th Cir. 1993).

99. Wilton v. Seven Falls Co., 515 U.S. 277, 279 (1995). 
Group, informed London Underwriters of the pending litigation and sought coverage under commercial liability policies, but London Underwriters refused to defend or indemnify the Hill Group. ${ }^{100}$ That litigation resulted in a verdict in excess of $\$ 100$ million against the Hill Group, and the Hill Group informed London Underwriters of the verdict. $^{101}$ London Underwriters sought a declaratory judgment in federal court that it was not liable under the policy. ${ }^{102}$ After negotiations, London Underwriters dismissed the case, but the Hill Group agreed to give two weeks' notice if it intended to sue on the policy. ${ }^{103}$ The Hill Group gave notice of its intent to sue on February 23, 1993, and the next day, London Underwriters filed its declaratory judgment claim in federal court. ${ }^{104}$ About a month later, the Hill Group filed its suit in state court in Texas and moved to dismiss or stay the declaratory judgment action in federal court. ${ }^{105}$ The district court stayed the action, reasoning "that the state lawsuit pending in [Texas state court] encompassed the same coverage issues raised in the declaratory judgment action" and finding "that a stay was warranted in order to avoid piecemeal litigation and to bar London Underwriters' attempts at forum shopping."106

Despite London Underwriters' argument that Colorado River and subsequent cases ${ }^{107}$ made Brillhart "an outmoded relic of another era," the Supreme Court emphasized that Colorado River and later cases were not in the context of declaratory judgments. ${ }^{108}$ The Court recognized that the Declaratory Judgment Act "confer[s] on federal courts unique and substantial discretion in deciding whether to declare the rights of litigants." 109 The use of "may" in the statute "distinguish[es] the declaratory judgment context from other areas of the law in which

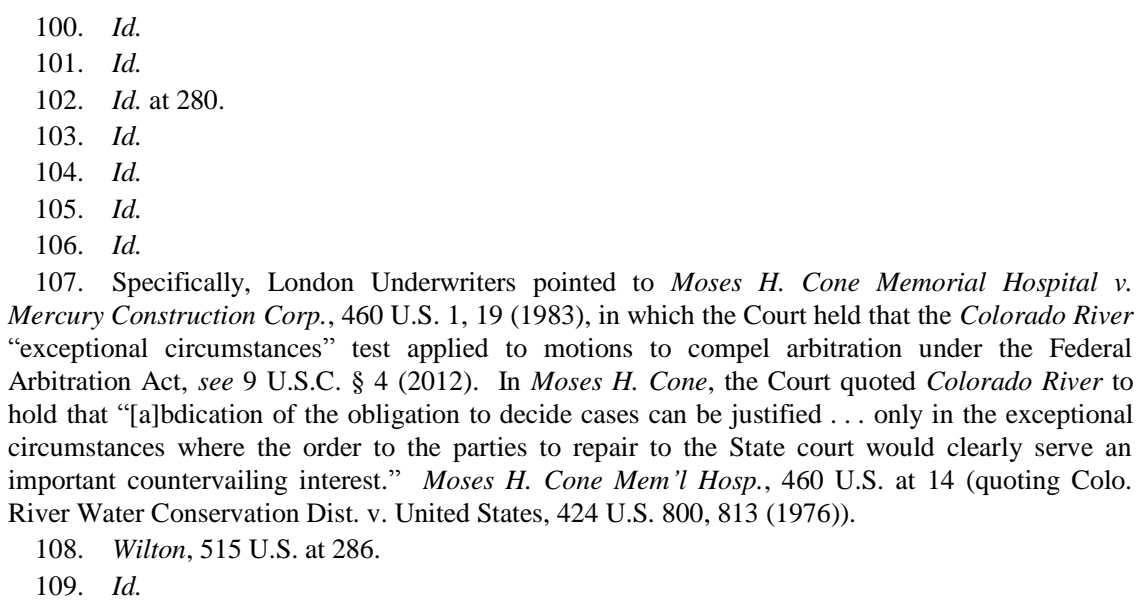


concepts of discretion surface." 110 Thus, the Declaratory Judgment Act is "an enabling Act, which confers a discretion on the courts rather than an absolute right upon the litigant," 111 and "the normal principle that federal courts should adjudicate claims within their jurisdiction yields to considerations of practicality and wise judicial administration."

The Supreme Court therefore clarified that in the context of declaratory judgments, district courts continued to possess broad discretion in deciding whether to grant relief. ${ }^{113}$ No longer would Colorado River and subsequent cases cause any confusion about the standard for declining to hear claims for declaratory relief. Only for claims seeking nondeclaratory relief had the Court imposed a much more restrictive standard in Colorado River, permitting a district court to decline to hear a case only in exceptional circumstances.

\section{THE CIRCUIT SPLIT OVER MIXED COMPLAINTS}

Despite Wilton's clarification about the standard for district courts not to decide declaratory judgment claims, that decision left open some issues about the standard for not deciding claims involving declaratory relief. Although the Supreme Court has articulated a clear standard for complaints that sought exclusively one type of relief - either declaratory or nondeclaratory - the Court has never given such guidance for mixed complaints. Unsurprisingly, a circuit split has subsequently developed on this question.

This circuit split includes four distinct approaches. The first approach is that the court never applies the Brillhart/Wilton doctrine to mixed claims. The second approach is that the court must determine if the claims for nondeclaratory relief are jurisdictionally independent from the claims for declaratory relief, and if so, apply the Colorado River doctrine. The third approach is that the court looks to the "heart of the

110. Id. at 287.

111. Id. (quoting Pub. Serv. Comm'n v. Wycoff Co., 344 U.S. 237, 241 (1952)); see also Pub. Affairs Assocs., Inc. v. Rickover, 369 U.S. 111, 112 (1962) ("The Declaratory Judgment Act was an authorization, not a command. It gave the federal courts competence to make a declaration of rights; it did not impose a duty to do so.").

112. Wilton, 515 U.S. at 288; see also id. ("By the Declaratory Judgment Act, Congress sought to place a remedial arrow in the district court's quiver; it created an opportunity, rather than a duty, to grant a new form of relief to qualifying litigants."). The Court did note that in most cases, "a stay [rather than a dismissal] will often be the preferable course, because it assures that the federal action can proceed without risk of a time bar if the state case, for any reason, fails to resolve the matter in controversy." Id. at 290 n.2.

113. For discussion and analysis of Wilton, see generally Giesel, supra note 599. 
complaint" and applies the Brillhart/Wilton doctrine if the essence of the complaint seeks declaratory relief. The final approach is that the court separates the claims for declaratory and nondeclaratory relief and applies the appropriate standard to each type of claim.

\section{A. The First Approach: Brillhart/Wilton Never Applies}

Four circuits - the Second, Fourth, Fifth, and Tenth - have adopted this approach. These courts have adopted this bright-line, categorical rule that prohibits district courts from applying the Brillhart/Wilton doctrine if a complaint includes any claims that seek nondeclaratory relief.

The Fifth Circuit was an early adopter of this view, doing so in 1994 in Southwind Aviation, Inc. v. Bergen Aviation, Inc. ${ }^{114}$ In that case, Southwind contracted with Bergen to repair an aircraft. ${ }^{115}$ After the repairs took longer and cost more than initially anticipated, Bergan filed suit against Southwind in Texas state court, and Southwind later filed suit in federal court. ${ }^{116}$ Southwind sought declaratory relief and monetary damages from Bergan. ${ }^{117}$ The district court construed the case as one seeking declaratory relief, and it applied the more lenient Brillhart standard rather than the stricter Colorado River test. ${ }^{118}$

On appeal, the Fifth Circuit disagreed with the district court's analysis. After noting the difference in Brillhart and Colorado River, the court of appeals recognized that the case involved nondeclaratory relief claims in addition to the ones for declaratory relief. ${ }^{119}$ Because Southwind sought both declaratory and nondeclaratory relief, the court proclaimed that the "[i]nclusion of these coercive remedies indisputably remove[d] this suit from the ambit of a declaratory judgment action." ${ }^{\prime 20}$ Therefore, the district court erred in applying Brillhart, and the court of appeals remanded the case for the district court to apply Colorado River,

114. Southwind Aviation, Inc. v. Bergen Aviation, Inc., 23 F.3d 948, 950-51 (5th Cir. 1994) (per curiam).

This case was actually decided before Wilton, but because the Fifth Circuit had already interpreted Colorado River as not abrogating Brillhart, the Fifth Circuit could already face a mixedcomplaint question before Wilton was decided.

115. Id. at 949 .

116. Id. at $949-50$.

117. Id. at 951 .

118. Id.

119. Id. at $950-51$.

120. Id. at 951 . 
which the circuit court held was the proper standard for determining whether to abstain from deciding this mixed-complaint case. ${ }^{121}$

The Fifth Circuit has been so firm in this rule that it has applied the rule even when a party initially filed only claims for declaratory relief and did not add claims for nondeclaratory relief until after the opposing party moved to abstain. In Kelly Investment, Inc. $v$. Continental Common Corp. ${ }^{122}$ Continental Common had sued Kelly Investment ${ }^{123}$ in Texas state court, alleging a breach of promissory notes. ${ }^{124}$ While this litigation was ongoing, Kelly Investment sought multiple declaratory judgments relating to the promissory notes in Louisiana state court, which Continental Common removed to federal district court. ${ }^{125}$ After the case was removed and Continental Common moved to abstain, Kelly Investment added claims for monetary relief as well. ${ }^{126}$ The district court applied the Colorado River doctrine, despite the fact that Kelly Investment added its claims for money damages after Continental Common filed its motion to abstain. ${ }^{127}$

The Fifth Circuit agreed with the district court that the Colorado River test applied and that, on these facts, that test was not met. ${ }^{128}$ Specifically, as for the Brillhart/Wilton doctrine, the court observed that "Brillhart is only applicable 'when a district court is considering abstaining from exercising jurisdiction over a declaratory judgment action.' In contrast, when an action contains any claim for coercive relief, the Colorado River abstention doctrine is ordinarily applicable."129

Notably, in a footnote in Kelly Investment, the Fifth Circuit left open the door that this rule is not always applicable to mixed complaints. The court reasoned that Kelly Investment's claims for monetary damages were "not frivolous, and there is no evidence that Kelly added them solely as a means of defeating Brillhart."130 Hence, this "bright-line"

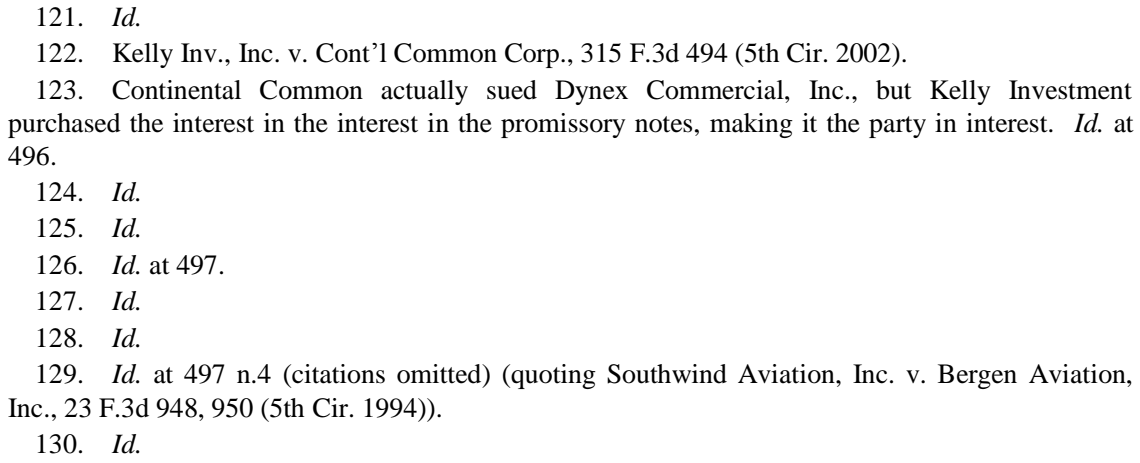


rule may not be quite as bright as it might first appear, and now the Fifth Circuit recognizes these two exceptions - that the claims for nondeclaratory relief were frivolous or added for the purpose of defeating application of the Brillhart/Wilton doctrine-as the "only" exceptions to its bright-line rule. ${ }^{131}$

The Second Circuit adopted this view in its 1999 decision in Village of Westfield $v$. Welch's. ${ }^{132}$ In this case, the Village of Westfield had built a new wastewater treatment facility, and it charged Welch's certain user fees based on Welch's grape-processing plant in the village. ${ }^{133}$ Welch's sued the village in New York state court in 1984, alleging that the village had overcharged Welch's for fees, and then the next year, Welch's filed a second suit, which was consolidated with the first suit, based on the village's changes to the user fees. ${ }^{134}$ This state court litigation continued for more than a decade, during which time the state court reversed itself on multiple occasions. ${ }^{135}$ In 1997-thirteen years after Welch's first filed suit - the village filed its own suit in state court, seeking fees from the previous two years from Welch's. ${ }^{136}$ Welch's removed the case to federal court and asserted counterclaims for a declaration of its rights and damages from the village. ${ }^{137}$ The district court granted the village's motion to stay the case based on the state court litigation. ${ }^{138}$

The Second Circuit ultimately reversed the district court. The court of appeals framed the issue in terms of Colorado River, noting courts' "virtually unflagging obligation' to exercise their jurisdiction," 139 unless the case fell into a specific exception such as the doctrines of Younger, ${ }^{140}$ Burford ${ }^{141}$ or Pullman ${ }^{142}$ abstention. ${ }^{143}$ The court held that the six-factor

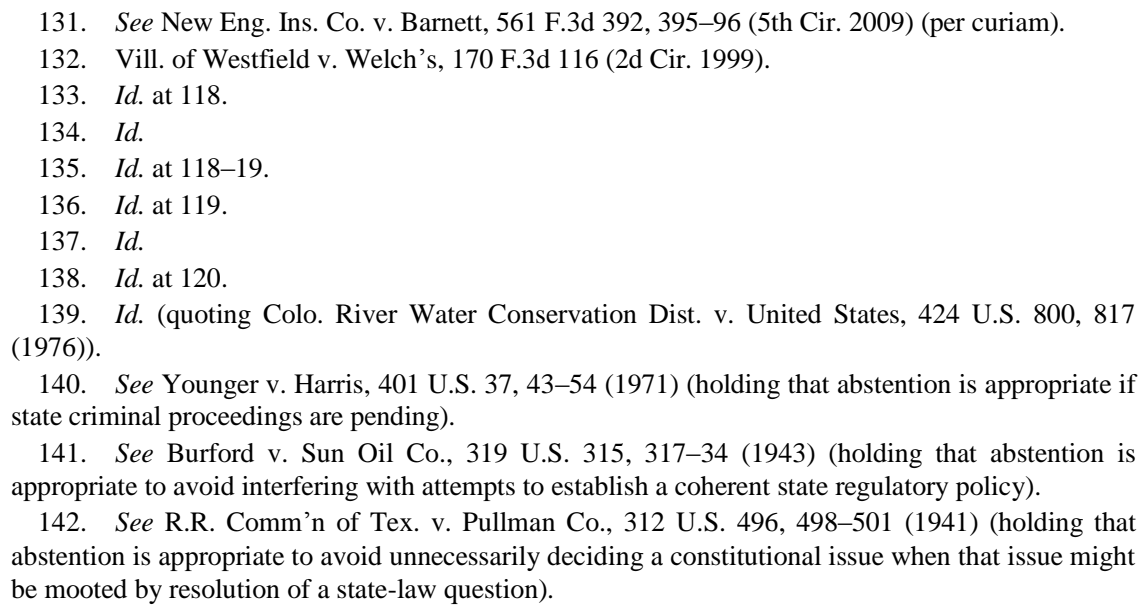

140. See Younger v. Harris, 401 U.S. 37, 43-54 (1971) (holding that abstention is appropriate if state criminal proceedings are pending).

141. See Burford v. Sun Oil Co., 319 U.S. 315, 317-34 (1943) (holding that abstention is appropriate to avoid interfering with attempts to establish a coherent state regulatory policy).

142. See R.R. Comm'n of Tex. v. Pullman Co., 312 U.S. 496, 498-501 (1941) (holding that abstention is appropriate to avoid unnecessarily deciding a constitutional issue when that issue might be mooted by resolution of a state-law question).

143. Vill. of Westfield, 170 F.3d at 120. 
test for determining whether Colorado River abstention is appropriate ${ }^{144}$ was not met here. ${ }^{145}$ The court addressed Wilton only in a footnote, observing that in that case the Supreme Court has clarified that Colorado River did not apply to claims for declaratory relief but that "Wilton [did] not apply here." 146 The court noted that although Welch's sought a declaratory judgment, it also sought damages from the village. ${ }^{147}$

Although the court never explicitly stated that it was applying a bright-line rule that the Brillhart/Wilton doctrine did not apply to a mixed complaint, that is the clear implication of this holding. But if this statement in a footnote about Wilton's inapplicability left any doubt as to the Second Circuit's position, the Second Circuit removed that doubt in Kanciper v. Suffolk County Society for the Prevention of Cruelty to Animals, Inc. ${ }^{148}$ There, the court explicitly held that "Wilton does not apply where, as here, a plaintiff does not seek purely declaratory relief, but also ... . seeks damages caused by the defendant's conduct."149

The Tenth Circuit is the third court of appeals that has adopted this bright-line rule, although it has not done so as explicitly as the Second and Fifth Circuits. In Sinclair Oil Corp. v. Amoco Production Co. ${ }^{150}$ the court drew a bright line between "declaratory actions" and "coercive actions," observing that unlike claims for coercive relief, "declaratory actions do not invoke the federal judiciary's 'virtually unflagging obligation' to exercise its jurisdiction." this position in United States v. City of Las Cruces $^{152}$ a decade later when the court applied the Brillhart/Wilton standard when the plaintiff sought "only declaratory relief." 153 The court focused on the "nature of the

144. See Moses H. Cone Mem'l Hosp. v. Mercury Constr. Corp., 460 U.S. 1, 16 (1983) (setting forth the factors a court should consider in determining whether to abstain under Colorado River).

145. Vill. of Westfield, 170 F.3d at 124-25.

146. Id. at 124 n.5.

147. Id.

148. Kanciper v. Suffolk Cty. Soc'y for the Prevention of Cruelty to Animals, Inc., 722 F.3d 88 (2d Cir. 2013).

149. Id. at 93 (quoting Niagra Mohawk Power Corp. v. Hudson River-Black River Regulating Dist., 673 F.3d 84, 106 (2d Cir. 2012)). In Niagra Mohawk Power Corp., the Second Circuit discussed whether abstention under the Brillhart/Wilton doctrine was appropriate in a mixedcomplaint case, despite the clear language in Village of Westfield. See Niagra Mohawk Power Corp., 673 F.3d at 104-06. This discussion suggests that the court did not consider Village of Westfield not to be controlling, but its reasoning gave the court no pause to treat this language as the basis for the holding in Kanciper.

150. Sinclair Oil Corp. v. Amoco Prod. Co., 982 F.2d 437 (10th Cir. 1992).

151. Id. at 440 .

152. United States v. City of Las Cruces, 289 F.3d 1170 (10th Cir. 2002).

153. Id. at 1181 (emphasis added). 
relief requested ..., not the jurisdictional basis of the suit," to determine whether the case was declaratory or coercive in nature. ${ }^{154}$

Finally, the Fourth Circuit adopted this view in 2015 in its decision in vonRosenberg $v$. Lawrence. ${ }^{155}$ In that case, two Episcopal clergymen disputed who was the proper leader of the Diocese of South Carolina, and vonRosenberg sued Lawrence, seeking declaratory and nondeclaratory relief. ${ }^{156}$ This included claims under the Lanham Act, ${ }^{157}$ which are subject to exclusive federal jurisdiction. ${ }^{158}$ Meanwhile, some of Lawrence's supporters had previously sued vonRosenberg in state court on claims arising from the same dispute. ${ }^{159}$ Lawrence moved to stay the case in federal court, and the district court granted the stay under Brillhart/Wilton. ${ }^{160}$ The Fourth Circuit vacated that order and remanded the case, holding that the district court should have applied Colorado River. ${ }^{161}$ The court of appeals reasoned that applying Brillhart/Wilton to mixed complaints "would ignore the very different justifications for the two abstention standards" and that Brillhart/Wilton "provides a poor fit for causes of action over which a federal court generally must exercise jurisdiction." 162 Stating that it "join[ed]" the position adopted by the Second, Fifth, and Tenth Circuits, the court held that adopting another rule "would deprive a plaintiff of access to a federal forum simply because he sought declaratory relief in addition to an injunction or money damages." 163

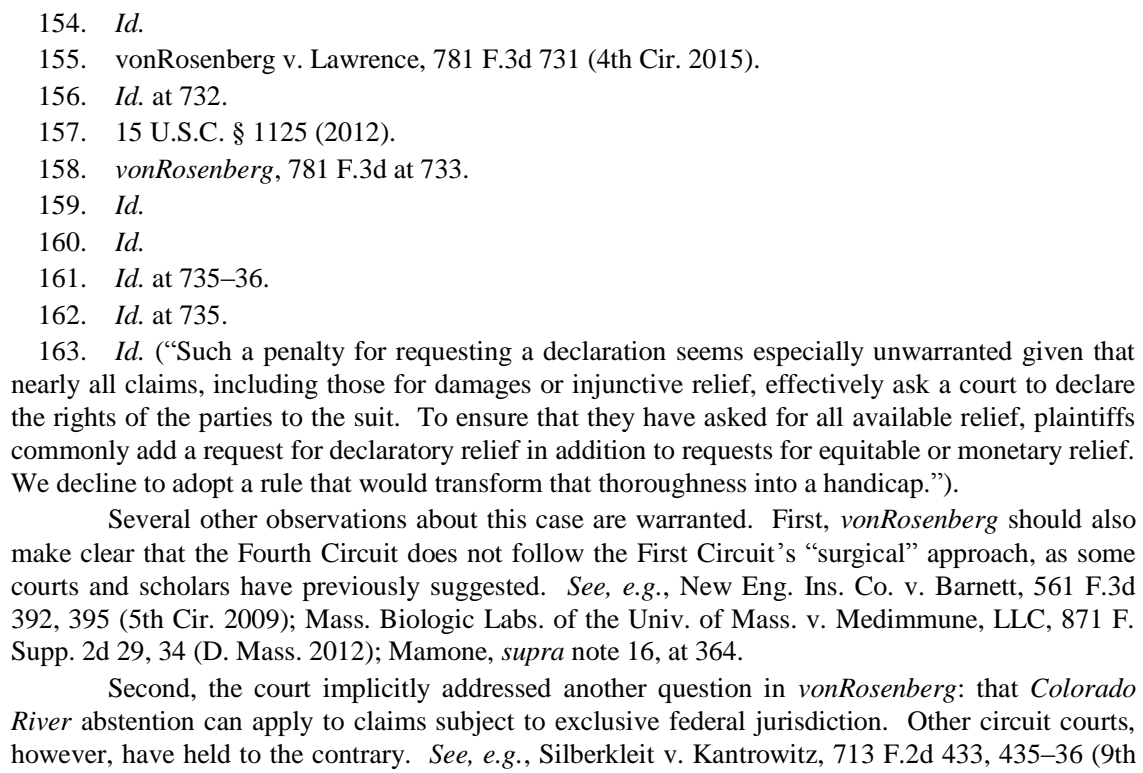

163. Id. ("Such a penalty for requesting a declaration seems especially unwarranted given that nearly all claims, including those for damages or injunctive relief, effectively ask a court to declare the rights of the parties to the suit. To ensure that they have asked for all available relief, plaintiffs commonly add a request for declaratory relief in addition to requests for equitable or monetary relief. We decline to adopt a rule that would transform that thoroughness into a handicap.").

Several other observations about this case are warranted. First, vonRosenberg should also make clear that the Fourth Circuit does not follow the First Circuit's "surgical" approach, as some courts and scholars have previously suggested. See, e.g., New Eng. Ins. Co. v. Barnett, 561 F.3d 392, 395 (5th Cir. 2009); Mass. Biologic Labs. of the Univ. of Mass. v. Medimmune, LLC, 871 F. Supp. 2d 29, 34 (D. Mass. 2012); Mamone, supra note 16, at 364.

Second, the court implicitly addressed another question in vonRosenberg: that Colorado River abstention can apply to claims subject to exclusive federal jurisdiction. Other circuit courts, however, have held to the contrary. See, e.g., Silberkleit v. Kantrowitz, 713 F.2d 433, 435-36 (9th 


\section{B. The Second Approach: Brillhart/Wilton Applies Only if Claims for Nondeclaratory Relief Are Not Jurisdictionally Independent}

This second approach, adopted by the Seventh and Ninth Circuits, takes a more nuanced approach than the bright-line rule discussed in Section A. Courts adhering to this approach consider the particular claims in a mixed complaint, determining if the claims for nondeclaratory relief are jurisdictionally independent of the claims for declaratory relief. If the claims for nondeclaratory relief are independent, then the court will not apply the Brillhart/Wilton standard; on the other hand, if those claims are not independent, then the court will apply this more lenient standard.

The Ninth Circuit is credited with first adopting this approach. ${ }^{164}$ Faced with another appeal in "a seemingly never-ending bout of litigation," 165 the court of appeals acknowledged that its jurisprudence "concerning the scope of the district court's discretion to decline jurisdiction over declaratory claims joined with other causes of action [had] been less than crystal clear."166 "The court noted that in some cases it had "applied the principle that "when other claims are joined with an action for declaratory relief (e.g., bad faith, breach of contract, breach of fiduciary duty, rescission, or claims for other monetary relief), the district court should not, as a general rule, remand or decline to entertain the claim for declaratory relief." 167 The court noted that in other cases, however, it had "concluded that the presence of claims for monetary relief did not require the district court to accept jurisdiction under the Declaratory Judgment Act." 168

The court clarified that in mixed-complaint cases

[t]he appropriate inquiry for a district court in a Declaratory Judgment Act case is to determine whether there are claims in the case that exist independent of any request for purely declaratory relief, that is, claims

\footnotetext{
Cir. 1983); Andrea Theatres, Inc. v. Theatre Confections, Inc., 787 F.2d 59, 63 (2d Cir. 1986) Courts' division on this question is becoming more prominent, and it is a question I will take up in a forthcoming article.

164. See R.R. Street \& Co. v. Vulcan Materials Co., 569 F.3d 711, 715-16 (7th Cir. 2009) (relying on United Nat'l Ins. Co. v. R\&D Latex Corp., 242 F.3d 1102, 1112 (9th Cir. 2001), as the basis for this approach).

165. R\&D Latex Corp., 242 F.3d at 1105.

166. Id. at 1112.

167. Id. (quoting Gov't Emps. Ins. Co. v. Dizol, 133 F.3d 1220, 1225 (9th Cir. 1998)).

168. Id. (citing Golden Eagle Ins. Co. v. Travelers Cos., 103 F.3d 750, 753 (9th Cir. 1996); Emp'rs Reinsurance Corp. v. Karussos, 65 F.3d 796, 798 (9th Cir. 1995)).
} 
that would continue to exist if the request for a declaration simply dropped from the case. ${ }^{16}$

Describing this test in more detail, the court wrote:

The proper analysis, then, must be whether the claim for monetary relief is independent in the sense that it could be litigated in federal court even if no declaratory claim had been filed. In other words, the district court should consider whether it has subject matter jurisdiction over the monetary claim alone, and if so, whether that claim must be joined with one for declaratory relief.

The Seventh Circuit undertook a detailed analysis of this approach in R.R. Street \& Co., Inc. v. Vulcan Materials Co. ${ }^{171}$ a case that provides a useful case study of this approach in practice. There, Vulcan entered into an agreement with R.R. Street that made R.R. Street the exclusive distributor of a Vulcan product and required Vulcan to defend and indemnify R.R. Street for all claims brought against R.R. Street based on that company's distribution of Vulcan's product. ${ }^{172}$ Vulcan refused to defend R.R. Street in several lawsuits filed based on harms from the product R.R. Street was distributing. ${ }^{173}$ National Union Fire Insurance Company-an insurer that had policies with Vulcan-had been defending R.R. Street in these lawsuits based on a separate policy that National Union had with R.R. Street. ${ }^{174}$ R.R. Street and National Union filed suit against Vulcan in the Northern District of Illinois, seeking a declaration that Vulcan was obligated to defend and indemnify R.R. Street and bringing claims for breach of contract, common-law indemnity, and promissory estoppel, for which the plaintiffs sought money damages. ${ }^{175}$ The district court determined that the Wilton/Brillhart doctrine applied to the entire case because "the plaintiffs' claims for damages were dependent upon their claim for declaratory relief," concluding that the case should be dismissed. ${ }^{176}$

The Seventh Circuit disagreed with this conclusion. After noting the

169. Id. (quoting Snodgrass v. Provident Life \& Accident Ins. Co., 147 F.3d 1163, 1167-68 (9th Cir. 1998) (per curiam)).

170. Id. at 1113 .

171. R.R. Street \& Co. v. Vulcan Materials Co., 569 F.3d 711 (7th Cir. 2009).

172. Id. at 713 .

173. Id. at $713-14$.

174. Id. at 713 .

175. Id. at 713-14. National Union had earlier filed a separate suit in California state court seeking a declaration that it owed no duty to Vulcan under the insurance policies. Id. at 713 .

176. Id. at 714 . 
various positions taken by other circuit courts, ${ }^{177}$ the Seventh Circuit adopted the Ninth Circuit's position. ${ }^{178}$ The court reasoned that this position, although perhaps not as easy to apply as the bright-line approach of the Second, Fourth, Fifth, and Tenth Circuits, preserved the "unique and substantial discretion" that district courts enjoy over whether to hear claims for declaratory relief. ${ }^{179}$ The court articulated this approach in the following test:

Where state and federal proceedings are parallel and the federal suit contains claims for both declaratory and non-declaratory relief, the district court should determine whether the claims seeking nondeclaratory relief are independent of the declaratory claim. If they are not, the court can exercise its discretion under Wilton/Brillhart and abstain from hearing the entire action. But if they are, the Wilton/Brillhart doctrine does not apply and, subject to the presence of exceptional circumstances under the Colorado River doctrine, the court must hear the independent non-declaratory claims. The district court then should retain the declaratory claim under Wilton/Brillhart (along with any dependent non-declaratory claims) in order to avoid piecemeal litigation.

The Seventh Circuit then explained, "[a] claim for non-declaratory relief is 'independent' of the declaratory claim if: 1) it has its own federal subject-matter-jurisdictional basis, and 2) its viability is not wholly dependent upon the success of the declaratory claim."181

Applying this test to this case, the Seventh Circuit held that the district court erred in applying the Wilton/Brillhart doctrine because "the non-declaratory claims are independent of the declaratory claim because they could stand alone in federal court-both jurisdictionally and substantively-irrespective of the declaratory claim."

\section{The Third Approach: Brillhart/Wilton Applies if the Heart of the Complaint Seeks Declaratory Relief}

The third approach to mixed-complaint cases is the "heart of the complaint" rule. Like the jurisdictional-independence rule, this approach

177. Id. at 715-16. This overview provides a useful and easy-to-follow guide (at least theoretically) for applying this approach.

178. Id. at 716 .

179. Id. (quoting Wilton v. Seven Falls Co., 515 U.S. 277, 286 (1995)).

180. Id. at 716-17 (footnotes omitted).

181. Id. at 716 n.6.

182. Id. at 717 . 
focuses on the factual allegations in the complaint and the relationship between claims seeking declaratory and nondeclaratory relief to determine the "essence of the suit."183 If the claims are fundamentally declaratory in nature, then the Brillhart/Wilton doctrine applies; if, however, the claims are at their core nondeclaratory, then the Colorado River doctrine applies. ${ }^{184}$ Put another way, "[i]f the outcome of the coercive claims hinges on the outcome of the declaratory ones, Wilton's standard governs; conversely, if the opposite applies, Colorado River's standard applies."

This approach is identified with the Eighth Circuit's decision in Royal Indemnity Co. v. Apex Oil Co., ${ }^{186}$ which involved Royal Indemnity's mixed complaint seeking relief from Apex Oil and various insurance companies related to contaminants that Apex Oil allegedly deposited into the soil surrounding its refinery. ${ }^{187}$ After the United States, the State of Illinois, and individuals sued Apex Oil over these contaminants, Apex Oil sued Royal Indemnity and other companies in Illinois state court, seeking a declaration of the parties' rights and duties. ${ }^{188}$ Royal Indemnity then sued Apex Oil and other insurance companies in federal court in the Eastern District of Missouri. ${ }^{189}$ Apex Oil moved to dismiss this suit based on the fact that it was parallel to the case in Illinois state court. ${ }^{190}$ Applying the Brillhart/Wilton doctrine, the district court dismissed the case. ${ }^{191}$

On appeal, the Eighth Circuit noted the "uniqueness" of the Brillhart/Wilton doctrine's relaxed standard for abstention. ${ }^{192}$ It

183. Royal Indem. Co. v. Apex Oil Co., 511 F.3d 788, $793-94$ (8th Cir. 2008).

184. Mamone distinguishes the approach of the Eighth Circuit, which he calls the "essence of the suit" rule, from the approach of various district courts, which he refers to as the "heart of the action" rule. Mamone, supra note 16, at 366-68. Given that these approaches seem indistinguishable apart from their language, they need not be categorized separately. Compare Royal Indem. Co., 511 F.3d at 793-96 (applying essence-of-the-suit rule and finding Brillhart/Wilton applied to declaratory suit seeking monetary damages as well), with ITT Indus., Inc. v. Pac. Emp'rs Ins. Co., 427 F. Supp. 2d 552, 557 (E.D. Pa. 2006) (applying heart-of-the-action rule and finding Brillhart/Wilton applied to declaratory suit that also involved a breach of contract claim).

185. ITT Indus., Inc., 427 F. Supp. 2d at 556 (quoting Coltec Indus. Inc. v. Cont'l Ins. Co., No. 04-5718, 2005 WL 1126951, at*2 (E.D. Pa. May 12, 2005)).

186. Royal Indem. Co., 511 F.3d 788 (8th Cir. 2008).

187. Id. at 791 .

188. Id.

189. Id. at 790-91.

190. Id. at 792. Apex Oil amended its complaint in Illinois state court to name the same entities as defendants in that case that Royal Indemnity had named in the federal court case. Id. at 791-92.

191. Id.

192. Id. at 793 . 
observed that "the fact that Royal Indemnity Company seeks monetary damages in addition to declaratory relief does not require a federal court automatically to apply the exceptional circumstances test articulated in Colorado River." "W3 "While noting the discretion afforded by the Declaratory Judgment Act, the court held that "a court may still abstain in a case in which a party seeks damages as well as a declaratory judgment so long as the further necessary or proper relief would be based on the court's decree so that the essence of the suit remains a declaratory judgment action." 194

Applying this rule to Royal Indemnity's suit, the court reasoned that the claims for monetary damages could "all be characterized as 'further necessary and proper relief' that Royal Indemnity Company seeks based on the requested declaratory judgment." 195 Quoting and then parsing the language of the complaint's prayer for relief, the court determined that "[i]f the district court were to reject Royal Indemnity Company's claims under the Declaratory Judgment Act, [Royal Indemnity Company] could not recover on the claims for contribution, subrogation, unjust enrichment and equitable estoppel." ${ }^{\text {196 }}$ These claims for nondeclaratory relief were therefore simply the logical result of any declaratory relief, making the declaratory relief the "essence of this lawsuit."197

\section{The Fourth Approach: Brillhart/Wilton Applies Always and Only to Claims for Declaratory Relief}

This fourth and final approach is one that arguably the First Circuit has adopted, albeit this circuit has not expressly waded into the mixedcomplaint debate. ${ }^{198}$ Rather, some courts ${ }^{199}$ and scholars ${ }^{200}$ have inferred

\footnotetext{
193. Id.

194. Id. at 793-94.

195. Id. at 794 .

196. Id.

197. Id.; see also ITT Indus., Inc. v. Pac. Emp'rs Ins. Co., 427 F. Supp. 2d 552, 557 (E.D. Pa. 2006) (applying the heart of the complaint rule and staying the case because it was at its essence a claim for declaratory relief). The similarities between the jurisdictional-independence approach and the heart of the complaint rule should be immediately apparent. The Seventh Circuit stated that its approach was similar to the "heart of the complaint" rule "except that the jurisdictional independence of the non-declaratory claims does not appear to be a consideration [in the heart of the complaint rule].” R.R. Street \& Co. v. Vulcan Materials Co., 569 F.3d 711, 716 n.5 (7th Cir. 2009). This theoretical difference likely would have little impact in practice, but it is theoretically significant, as Part III explains.

198. Given the lack of direct discussion of the mixed-complaint issue, one might fairly say that the First Circuit has never truly taken a position on this issue. See Mass. Biologic Labs. of the Univ. of Mass. v. MedImmune, LLC, 871 F. Supp. 2d 29, 35 (D. Mass. 2012) ("The First Circuit has not
} 
this approach from First Circuit case law. This approach seeks to separate - or disentangle — each claim, applying Colorado River to those seeking nondeclaratory relief while employing Brillhart/Wilton for those seeking declaratory relief.

In Rossi v. Gemma, ${ }^{201}$ the First Circuit faced a procedurally convoluted case in which the plaintiffs challenged Rhode Island's mechanic's lien statute. ${ }^{202}$ While their initial challenge to the statute was pending before the Rhode Island Supreme Court, the plaintiffs filed a $\S$ 1983 claim in federal court, seeking money damages, an injunction, and a declaration that the statute was unconstitutional. ${ }^{203}$ The district court abstained from hearing the federal claims under Colorado River and declined to exercise supplemental jurisdiction over the related state-law claims. $^{204}$

On appeal, the First Circuit decided to apply Younger abstention to the claims for nondeclaratory relief, to which the district court had applied Colorado River. ${ }^{205}$ Then, the court briefly observed that the district court had not needed to have found the Colorado River test met to abstain on the declaratory judgment claim because Brillhart/Wilton applied there, meaning that the district court enjoyed broad discretion on whether to abstain. ${ }^{206}$ The First Circuit never expressly described itself as resolving a mixed-complaint question, and in fact, the court appeared to have given no consideration to that issue. But from its unhesitating application of Brillhart/Wilton to a claim for declaratory relief after having applied a different abstention doctrine to the claims for nondeclaratory relief, courts have interpreted Rossi as adopting a disentanglement or "surgical" approach. ${ }^{207}$

\footnotetext{
yet staked out a clear position on the circuit split ...."). Nevertheless, other courts have found the First Circuit to have issued a controlling opinion, see, e.g., Seaton Ins. Co. v. Clearwater Ins. Co., 736 F. Supp. 2d 472, 475 (D.R.I. 2010), and even the District of Massachusetts decided to follow the Rossi court's approach because the First Circuit had "at least approved of, if not mandated" the "surgical" approach, see Mass. Biologic Labs., 871 F. Supp. 2d at 35. Moreover, given that this position offers a fourth possible resolution to the mixed-complaint issue, it is included in this discussion as another alternative.

199. See Seaton Ins. Co., 736 F. Supp. $2 d$ at 475.

200. See Mamone, supra note 16, at 364 .

201. Rossi v. Gemma, 489 F.3d 26 (1st Cir. 2007).

202. Id. at $27-28$.

203. Id. at $28-32$.

204. Id. at $32-33$.

205. Id. at 34-38.

206. Id. at 39 .

207. Teknor Apex Co. v. Hartford Acc. \& Indem. Co., No. 12-417S, 2012 WL 6840498, at *2-3 (D.R.I. Dec. 14, 2012), report and recommendation adopted, No. 12-417S, 2013 WL 140416 (D.R.I.
} 
These four approaches represent fundamentally different approaches to determining whether to apply the Colorado River doctrine or the Brillhart/Wilton doctrine to mixed-complaint cases. Each approach has benefits; indeed, that is why federal courts of appeals have adopted each of these approaches. Yet, as the next Part explains, the approaches are not, like men, created equal. ${ }^{208}$

\section{UNMIXING THE MESS BY GETTING TO THE HEART OF THE COMPLAINT}

The division among federal courts over how to handle abstention in mixed-complaint cases is obvious. How to resolve this division is, at least at first glance, less clear. On some level, each approach has intuitive appeal. But ultimately, the heart of the complaint rule is the best rule.

Reaching this conclusion requires developing criteria that appropriately weigh the strengths and weaknesses of each approach to mixed complaints within the context of America's judicial system. These criteria must account for the language of the statutes and judicial decisions that govern abstention and jurisdiction, consider the wise use of judicial resources, and permit courts to decide cases fairly. These concerns can be broken into four specific standards by which these approaches to mixed complaints can be measured: (1) preserving the discretionary language of the Declaratory Judgment Act while accounting for other jurisdictional statutes and the language of Colorado River; (2) promoting the wise use of judicial resources by ensuring that district courts have the necessary flexibility to manage their dockets wisely; (3) preventing plaintiffs from manipulating the judicial system by clever pleading; and (4) providing district courts the ability to reach the most just result given the particular facts of an individual case.

This Part examines these four standards, explaining why each is an appropriate tool by which to measure approaches to mixed complaints, how each of the four approaches stands up under the scrutiny of each standard, and ultimately why the heart of the complaint rule is the best approach to mixed complaints under these standards.

Jan. 11, 2013).

208. The DeClaration OF INDEPENDENCE para. 1 (U.S. 1776) ("We hold these Truths to be self-evident, that all men are created equal, that they are endowed by their Creator with certain unalienable Rights ...."). 


\section{A. Preserving the Discretion Provided by the Declaratory Judgment Act}

First, whatever approach is adopted must preserve the discretion that Congress gave to federal courts in the Declaratory Judgment Act while accounting for other related statutes and judicial decisions. Because Congress specifically granted courts discretion in the Declaratory Judgment Act, any resolution of the mixed-complaint question must respect Congress's choice without undermining any other choice that Congress has made. ${ }^{209}$

The Declaratory Judgment Act provides that a court "may declare the rights and other legal relations of any interested party seeking such declaration, whether or not further relief is or could be sought." ${ }^{210}$ This statutory language is "unique[]" in the discretion it grants to federal courts. $^{211}$ For example, federal-question jurisdiction under 28 U.S.C. $\S$ 1331 provides that "district courts shall have original jurisdiction of all civil actions arising under the Constitution, laws, or treaties of the United States." "212 Similarly, diversity jurisdiction under 28 U.S.C. § 1332 states that "district courts shall have original jurisdiction of all civil actions" that meet certain, well-known criteria. ${ }^{213}$ Even statutes granting jurisdiction in more specific scenarios use similar language of "shall have original jurisdiction" to confer jurisdiction. ${ }^{214}$ These different types of jurisdictional grants, when read in conjunction with Supreme Court decisions like Chief Justice Marshall's in Cohens, explain why courts have had to create abstention doctrines for cases brought under statutes like $\S 1331$ or $\S 1332$ but have been able to rely on the statutory language of $\S 2201$ to refrain from deciding cases seeking declaratory relief. $^{215}$

Additionally, other statutes that use "may" do so to describe the

209. Cf. Nat'l Fed'n of Indep. Bus. v. Sebelius, 132 S. Ct. 2566, 2615 (2012) (Ginsburg, J., concurring in part and dissenting in part) ("Whatever one thinks of the policy decision Congress made, it was Congress' prerogative to make it.").

210. 28 U.S.C. $\$ 2201$ (a) (2012) (emphasis added).

211. Royal Indem. Co. v. Apex Oil Co., 511 F.3d 788, 793 (8th Cir. 2008) (citing Wilton v. Seven Falls Co., 515 U.S. 277, 286-87 (1995)).

212. 28 U.S.C. $§ 1331$ (2012) (emphasis added).

213. 28 U.S.C. $§ 1332$ (2012) (emphasis added). These requirements include that the case involve more than $\$ 75,000$ and that the parties be citizens of different states, among other things. Id. $\S 1332(\mathrm{a})$.

214. See, e.g., 28 U.S.C. $§ 1363$ (2012) ("The district courts shall have original jurisdiction of any civil action brought for the protection of jurors' employment under section 1875 of this title.").

215. See Med. Assurance Co. v. Hellman, 610 F.3d 371, 378 (7th Cir. 2010) (explaining why the Brillhart/Wilton doctrine is not a traditional abstention doctrine like Colorado River). 
court in which a plaintiff can file suit, not to describe what the court is allowed to do, making them fundamentally inapposite from $\S 2201$. $^{216}$ The type of "may" in these other provisions has been interpreted as permitting a plaintiff to bring a claim in federal court or in state court. For instance, when analyzing whether state courts had concurrent jurisdiction over claims brought pursuant to the Racketeer Influenced and Corrupt Organizations Act, ${ }^{217}$ the Supreme Court reasoned that the statute "provides that suits of the kind described 'may' be brought in the federal district courts, not that they must be." 218 The Declaratory Judgment Act, by contrast, uses "may" in a way that gives courts latitude in whether to grant a certain type of relief.

These differences in the language of statutes are clear enough, but the question that flows from recognizing these differences is what effect those differences should have. In cases seeking only declaratory relief or only nondeclaratory relief, then the effect of the statutory language is obvious: Brillhart/Wilton applies to the claims for declaratory relief, and the appropriate judicially created abstention doctrine-such as Colorado River or Pullman - applies to the claims for nondeclaratory relief. Yet when a complaint seeks both types of relief, the challenge for a court is how to give effect to the language Congress has adopted in various sections of Title 28 of the U.S. Code. Giving effect to these grants is important because, as the Supreme Court recognized more than a century and half ago, Congress has the power to create inferior federal courts and to prescribe the scope of their jurisdiction. ${ }^{219}$ Thus, whatever jurisdiction Congress grants, courts should-indeed, must, unless an abstention

216. See, e.g., 31 U.S.C. § 3732(a) (2012) (providing that a False Claims Act case "may be brought in any judicial district" meeting certain criteria).

217. Racketeer Influenced and Corrupt Organization Act, Pub. L. No. 91-452, Title IX, 84 Stat. 941 (codified as amended at 18 U.S.C. §§ 1961-1968 (2012)).

218. Tafflin v. Levitt, 493 U.S. 455, 460-61 (1990) (quoting Charles Dowd Box Co. v. Courtney, 368 U.S. 502, 506 (1962)).

219. Sheldon v. Sill, 49 U.S. 441, 449 (1850) (“[I]t would seem to follow, also, that, having a right to prescribe, Congress may withhold from any court of its creation jurisdiction of any of the enumerated controversies. Courts created by statute can have no jurisdiction but such as the statute confers. No one of them can assert a just claim to jurisdiction exclusively conferred on another, or withheld from all.”); see also Lockerty v. Phillips, 319 U.S. 182, 187 (1943) (“The Congressional power to ordain and establish inferior courts includes the power 'of investing them with jurisdiction either limited, concurrent, or exclusive, and of withholding jurisdiction from them in the exact degrees and character which to Congress may seem proper for the public good." (quoting Cary v. Curtis, 44 U.S. 236, 245 (1845))); Wilburn v. Robinson, 480 F.3d 1140, 1144 (D.C. Cir. 2007) (observing that "only the Congress possesses authority to alter the subject-matter jurisdiction of the lower federal courts" (citing Kontrick v. Ryan, 540 U.S. 443, 452 (2004))). 
doctrine applies ${ }^{220}$ _exercise as Congress granted.

The heart of the complaint rule allows a court to exercise the discretion granted by Congress in $\S 2201$ in a mixed-complaint case. ${ }^{221}$ Under this rule, when a court determines that a complaint is, at its core, seeking declaratory relief, a court has the ability to decline to grant that relief. Because the claims for nondeclaratory relief are tangential to the real issue in the case, a court that decides not to decide the case is doing no harm to the jurisdictional provisions of $\S 1331$ or $\S 1332$. A case in federal court brought under either of those jurisdictional hooks would be heard (assuming Colorado River did not apply) if the case were really about those claims. But when the core issue of the case is about declaratory relief, tacked-on claims for nondeclaratory relief that do not get decided by a federal court should raise no serious concerns that a court is flouting its obligation to exercise jurisdiction. Indeed, the exceptions to the bright-line rule that the Fifth Circuit has adopted make this much clear. ${ }^{222}$ Thus, the heart of the complaint rule respects these jurisdictional statutes, so courts' worries that the heart of the complaint rule "fails to give adequate consideration to Colorado River" are unfounded. ${ }^{223}$

Of the remaining approaches, the rule that Brillhart/Wilton never applies to mixed complaints most obviously ignores the language of the Declaratory Judgment Act by taking away that discretion. It gives a court no opportunity to exercise the discretion over claims for declaratory relief that Congress granted. As one federal district court has observed, "[t]o eradicate that discretion simply because a coercive claim has been tacked onto what is, at its core, a declaratory judgment action would be... to marginalize Wilton, and to undermine the statutory

220. Cohens v. Virginia, 19 U.S. 264, 404 (1821) ("[Federal courts] have no more right to decline the exercise of jurisdiction which is given, than to usurp that which is not given.").

221. See, e.g., Columbia Gas of Pa. v. Am. Int'l Grp., No. 10-1131, 2011 WL 294520, at *2 (W.D. Pa. Jan. 27, 2011) ("In a 'pure' diversity matter, divorced from any interrelated declaratory claims, I would cleave to that obligation. In a case such as this one, however, which implicates statutorily-granted discretion, other important principles are entitled to careful regard."); ITT Indus., Inc. v. Pac. Emp'rs Ins. Co., 427 F. Supp. 2d 552, 557 (E.D. Pa. 2006) ("To apply the Colorado River standard to actions containing both declaratory judgment and coercive claims without an analysis of the facts at hand would be to ignore the Supreme Court's specific recognition that declaratory judgment actions necessitate a different treatment than other types of cases."); Martha A. Field, Removal Reform: A Solution for Federal Question Jurisdiction, Forum Shopping, and Duplicative State-Federal Litigation, 88 IND. L.J. 611, 665 (2013) ("If confined to cases in which only declaratory relief can be sought, the category of cases governed by Wilton is much reduced.").

222. See supra notes 130-31 and accompanying text.

223. Perelman v. Perelman, 688 F. Supp. 2d 367, 376 (E.D. Pa. 2010). 
scheme established by Congress."224 And as the Seventh Circuit said in rejecting this approach, "the mere fact that a litigant seeks some nonfrivolous, non-declaratory relief in addition to declaratory relief" should not obviate the Brillhart/Wilton doctrine. ${ }^{225}$ Indeed, this bright-line approach appears so myopically concerned with courts' obligation to exercise their jurisdiction over claims for nondeclaratory relief absent the application of Colorado River that it ignores the equally legitimate discretion granted by Congress in $\S 2201$. $^{226}$

The approach from the Seventh and Ninth Circuits that Brillhart/Wilton applies only when claims for nondeclaratory relief are not jurisdictionally independent is only marginally better - although it preserves discretion in some cases, it removes discretion in other cases. Realistically, a court following the heart of the complaint rule and a court following the independent claim rule will likely reach similar conclusions, because if a case is truly about declaratory relief, then the claim for nondeclaratory relief is less likely to be independent, whereas a case that is about nondeclaratory relief at its core will likely have independent claims for that coercive relief. Still, even if the difference in these approaches likely has little practical effect, the theoretical difference matters because it reflects how courts view constitutional structure. Congress has the constitutional authority to create federal courts (other than the Supreme Court, of course ${ }^{227}$ ) and to establish their jurisdiction and obligations to decide (or not to decide) cases, ${ }^{228}$ so giving effect to Congress's decisions is essential for preserving the rule of law. 229

Finally, the First Circuit's approach that the Brillhart/Wilton doctrine applies only to claims for declaratory relief fully respects Congress's choices. In fact, it does the best job of respecting all of the jurisdictional statutes that Congress has adopted. It therefore does well under this

224. Lexington Ins. Co. v. Rolison, 434 F. Supp. 2d 1228, 1237 (S.D. Ala. 2006).

225. R.R. Street \& Co. v. Vulcan Materials Co., 569 F.3d 711, 716 (7th Cir. 2009).

226. See, e.g., Black Sea Inv., Ltd. v. United Heritage Corp., 204 F.3d 647, 652 (5th Cir. 2000) ("When a party seeks both injunctive and declaratory relief, the appropriateness of abstention must be assessed according to the doctrine of Colorado River; the only potential exception to this general rule arises when a party's request for injunctive relief is either frivolous or is made solely to avoid application of the Brillhart standard.").

227. U.S. CONST. art. I, § 8, cl. 9.

228. See supra note 219 and accompanying text.

229. See, e.g., Wm. Grayson Lambert, Note, The Real Debate over the Senate's Role in the Confirmation Process, 61 DuKE L.J. 1283, 1317-19 (2012) (discussing the importance of the rule of law in a democratic society). 
standard for evaluating approaches to mixed complaints. But this approach has other flaws that make it less desirable when evaluated under other standards.

\section{B. Promoting Wise Judicial Administration}

Judicial economy is constantly on the minds of federal judges. ${ }^{230}$ As one court succinctly described the need for efficiently managing its docket: "Every day of trial this Court can save, even every hour of trial it can save in one case permits the Court to hear the claim of another litigant. This is of paramount importance and it is the essence of judicial economy." 231 Given the heavy caseload of federal courts and the time that it takes for cases to reach a resolution, ${ }^{232}$ federal judges understandably focus on judicial economy. Any resolution of the circuit split over mixed complaints must therefore take into account the need for courts to manage their dockets efficiently. ${ }^{233}$

The heart of the complaint rule promotes the wide judicial administration that is required for a well-functioning judiciary. ${ }^{234}$ It ensures that a court has sufficient flexibility to ensure that a case does not have to proceed unnecessarily because this approach has the "desirable feature[]" of "allow[ing] district courts to treat different cases differently based on the fundamental character of a particular action."235 As mixed-complaint cases involving abstention requests often arise in a context involving multiple lawsuits (that is, separate lawsuits filed in different courts; otherwise, the cases could simply be consolidated under

230. See, e.g., Bd. of Trs. of Constr. Laborers' Pension Tr. v. M.M. Sundt Constr. Co., 37 F.3d 1419, 1420 (9th Cir. 1994) ("Judicial economy is an important purpose of exhaustion requirements [for administrative remedies]." (citing McKart v. United States, 395 U.S. 185, 193-94 (1968))); Barrington Grp., Ltd. v. Genesys Software Sys., Inc., 239 F. Supp. 2d 870, 873 (E.D. Wis. 2003) ("Judicial economy is a particularly important concern when two actions involving the same parties and issues are pending in different districts.").

231. Goff v. Kroger Co., 647 F. Supp. 87, 88 (S.D. Ohio 1986).

232. See Federal Judicial Caseload Statistics 2014, United States CourTs (last visited Nov. 19, 2015), http://www.uscourts.gov/statistics-reports/federal-judicial-caseload-statistics-2014 (providing an overview of the caseload of federal courts).

233. Cf. Will v. Calvert Fire Ins. Co., 437 U.S. 655, 665 (1978) ("No one can seriously contend that a busy federal trial judge, confronted both with competing demands on his time for matters properly within his jurisdiction and with inevitable scheduling difficulties because of the unavailability of lawyers, parties, and witnesses, is not entrusted with a wide latitude in setting his own calendar.").

234. Lexington Ins. Co. v. Rolison, 434 F. Supp. 2d 1228, 1237 (S.D. Ala. 2006) (recognizing that the heart of the complaint rule promotes "wise judicial administration").

235. Id. at $1237-38$. 
Federal Rule of Civil Procedure 42(a) ${ }^{236}$ ), courts need the ability "to avert wasteful, duplicative declaratory litigation on exclusively state law issues in federal court running alongside parallel state litigation on the same issues, with concomitant disruption to the time-honored values of federalism, comity and efficiency" when the complaint does not truly present a case that warrants adjudication in federal court. ${ }^{237}$ By preserving a court's authority to look at the core of a complaint, the heart of the complaint protects this need. ${ }^{238}$

None of the other approaches ensures that federal courts can manage their dockets as wisely as the heart of the complaint rule. First, the Second, Fourth, Fifth, and Tenth Circuits' approach that forbids courts from applying the Brillhart/Wilton doctrine in mixed-complaint cases leaves little room for a court to consider judicial administration. Although judicial administration is central to the Colorado River analysis, ${ }^{239}$ the scope of that analysis is narrow compared to Brillhart/Wilton. ${ }^{240}$ Under this approach, if a plaintiff includes any claim seeking nondeclaratory relief in a complaint, the court cannot refrain from deciding the case, no matter the circumstance, unless Colorado

236. FED. R. CIV. P. 42(a) ("If actions before the court involve a common question of law or fact, the court may: (1) join for hearing or trial any or all matters at issue in the actions; (2) consolidate the actions; or (3) issue any other orders to avoid unnecessary cost or delay.").

237. Lexington Ins. Co., 434 F. Supp. 2d at 1237; see also Coltec Indus. Inc. v. Cont'1 Ins. Co., No. CIV.A. 04-5718, 2005 WL 1126951, at*3 (E.D. Pa. May 11, 2005) ("The course we follow enables district courts to conserve their resources by staying a case that would duplicate state litigation.").

238. Lexington Ins. Co., 434 F. Supp. 2d at 1237 ("If peripheral monetary claims could deprive district courts of the discretion granted them by the Declaratory Judgment Act to hear or not to hear what are fundamentally declaratory judgment actions, then such claims would render federal courts virtually powerless (save for the rare case in which Colorado River abstention is warranted) to avert wasteful, duplicative declaratory litigation on exclusively state law issues in federal court running alongside parallel state litigation on the same issues, with concomitant disruption to the timehonored values of federalism, comity and efficiency."); Coltec, 2005 WL 1126951, at *3 ("Professor Chemerinsky has stressed the important reality that this duplication can squander judicial resources 'because ultimately only one of the jurisdictions will actually decide the case. Once one court renders a ruling, the other court will be obliged to halt its proceedings and give res judicata effect to the decision."' (quoting ERWIN CHEMERINSKY, FEDERAL JURISDICTION § 14.1, at 839 (4th ed. 2003))).

239. See Moses H. Cone Mem'l Hosp. v. Mercury Constr. Corp., 460 U.S. 1, 15 (1983) (quoting Colo. River Water Conservation Dist. v. United States, 424 U.S. 800, 818 (1976)).

240. Chase Brexton Health Servs., Inc. v. Maryland, 411 F.3d 457, 463 (4th Cir. 2005) ("[I]n assessing whether Colorado River abstention is appropriate, a district court must remain mindful that this form of abstention 'is an extraordinary and narrow exception to the duty of a District Court to adjudicate a controversy properly before it' and that '[a]bdication of the obligation to decide cases can be justified under [abstention] only in the exceptional circumstances where the order to the parties to repair to the State court would clearly serve an important countervailing interest." (second and third alterations in original) (quoting Colo. River Water Conservation Dist., 424 U.S. at 813)). 
River abstention applies. ${ }^{241}$ Thus, no matter how duplicative the case, a federal judge must hear it except for the most limited of circumstancesthe judge cannot save a day or an hour to devote to other cases. ${ }^{242}$

Ironically, this approach that elevates Colorado River undermines one of that doctrine's primary purposes. The Supreme Court based its decision in Colorado River on "wise judicial administration." 243 Brillhart/Wilton actually provides a court with far more flexibility to make decisions that promote such administration. Granted, the Court in Colorado River also emphasized the limited circumstances under which courts could decline to exercise jurisdiction. ${ }^{244}$ But that concept is based on the idea that federal courts have been granted jurisdiction to decide certain types of cases and that courts have a duty to perform the tasks assigned to them. ${ }^{245}$ When a case includes a claim for declaratory relief, Congress has expressly given courts broader leeway in deciding whether to decide the case, a point that the rigid approach that always requires the application of Colorado River ignores. ${ }^{246}$ Of course, a mixed complaint also contains claims for nondeclaratory relief, for which courts have less discretion to abstain, which might favor the rule applying Brillhart/Wilton to claims for declaratory relief only. The heart of the complaint rule, however, does not undermine the "rule" that federal courts should exercise jurisdiction. ${ }^{247}$ Rather, its application simply ensures that a plaintiff cannot cleverly plead his way into federal court by taking advantage of Colorado River. ${ }^{248}$

Next, the Seventh and Ninth Circuits' approach that allows the application of Brillhart/Wilton only when claims for nondeclaratory relief are jurisdictionally independent guarantees too little discretion to

241. See, e.g., Lexington Ins. Co., 434 F. Supp. 2d at 1237 ("To eradicate that discretion simply because a coercive claim has been tacked onto what is, at its core, a declaratory judgment action would be to jettison those same considerations of practicality and wise judicial administration [and] to exalt form over substance ....").

242. See Goff v. Kroger Co., 647 F. Supp. 87, 88 (S.D. Ohio 1986) ("Every day of trial this Court can save, even every hour of trial it can save in one case permits the Court to hear the claim of another litigant.").

243. Colo. River Water Conservation Dist., 424 U.S. at 818.

244. Id. at 813-14.

245. See id. at 813-16 (describing the various bases for abstention).

246. See supra notes 210-18 and accompanying text (comparing the texts of permissive and mandatory congressional grants of jurisdiction).

247. Colo. River Water Conservation Dist., 424 U.S. at 813.

248. See infra Part III.C; see also Kelly Inv., Inc. v. Cont'l Common Corp., 315 F.3d 494, 497 n.4 (5th Cir. 2002) (providing an exception to the bright-line rule when a claim for nondeclaratory relief was "added . . . solely as a means of defeating Brillhart"). 
ensure that courts can wisely manage their dockets. Although in practice this test may function similarly to the heart of the complaint rule, again, the theoretical differences matter. Not applying Brillhart/Wilton simply because some claims for nondeclaratory relief have their own jurisdictional hook still leaves the hypothetical situation in which a court is left convinced that it should not decide a case but left with no choice but to decide it.

Finally, the First Circuit's approach that permits courts to apply Brillhart/Wilton only to claims for declaratory relief leaves a federal court in essentially the same position as the approach that says Brillhart/Wilton never applies to mixed-complaint cases. When the Brillhart/Wilton applies to claims for declaratory relief only, the federal court can apply the more lenient standard of that doctrine to some claims, but then it is left to apply Colorado River to the claims for nondeclaratory relief. Hence, unless those more stringent requirements were met, the court would still be forced to adjudicate a case that it otherwise believes should not be heard in federal court, but, with only Colorado River as a basis to abstain, it cannot do so.

\section{Preventing Procedural Gamesmanship}

Another important concern is the need to prevent procedural gamesmanship. Courts have repeatedly rejected litigants' attempts to manipulate the judicial system. ${ }^{249}$ Indeed, "[n]o rational judicial system can tolerate manipulation." ${ }^{250}$ Courts must have rules that they can enforce without litigants finding loopholes to avoid the result that a rule clearly contemplates. ${ }^{251}$ Moreover, procedural gamesmanship opens the metaphorical door for duplicative litigation and conflicting judicial orders, which benefits no one but the manipulator (assuming the manipulator's plan works outs as expected) and only undermines the

249. See, e.g., McCoy v. Iberdrola Renewables, Inc., 760 F.3d 674, 684 (7th Cir. 2014) ("Outland finally raised the choice of law issue only as this litigation approached the two-year mark and after it had lost on the merits under Illinois law. We do not condone such procedural gamesmanship."); Sansotta v. Town of Nags Head, 724 F.3d 533, 547-48 (4th Cir. 2013) (holding that a state or its political subdivision cannot remove a case filed in state court to federal court and then invoke the state-litigation requirement of Williamson County Regional Planning Commission v. Hamilton Bank, 473 U.S. 172 (1985), to contend that the case is not ripe).

250. Newark Motor Inn Corp. v. Holiday Inns, Inc., No. 77-582, 1980 WL 1875, at *4 (D.N.J. Feb. 1, 1980).

251. Cf. Ferris v. Cuevas, 118 F.3d 122, 130 (2d Cir. 1997) (interpreting a previous decision so as to have that case "not provide a loophole for attorney-plaintiffs ... to manipulate the judicial system"). 
sound administration of justice. ${ }^{252}$

This issue focuses on preventing litigants from pleading a case in such a way that a court is required to apply one abstention doctrine over another, simply because of how a case is pled instead of based on the merits of the case. Federal Rule of Civil Procedure 8 requires only "a short and plain statement of the claim." ${ }^{253}$ The purpose of this notice pleading is to avoid the technical pleading formalities of bygone eras. ${ }^{254}$ Consistent with this principle, litigants should not have to draft complaints that meet overly technical requirements to get a case heard in court. But at the same time, they should not be able to draft a complaint artfully (or craftily) to avoid unfavorable but should-be-applicable legal rules.

The heart of the complaint rule does the best job of preventing litigants from manipulating the judicial system. Under this rule, a court is not bound by the formalities of a pleading because the court can examine the complaint to determine what the real issue of the case is and what type of relief is central to the case. Thus, a plaintiff cannot insert a claim for nondeclaratory relief into a complaint to avoid Brillhart/Wilton and instead be subject to Colorado River. ${ }^{255}$ The heart of the complaint rule therefore ensures that a court has the flexibility to apply whichever standard is appropriate in any given case.

Again, the approach of the Second, Fourth, Fifth, and Tenth Circuits is particularly troublesome in this context. Although some of these courts have carved out an exception for "frivolous" claims for nondeclaratory relief, ${ }^{256}$ this exception fails to address sufficiently the obvious problem with this approach: a plaintiff can simply "toss[]" in a claim for nondeclaratory relief and preclude the application of Brillhart/Wilton doctrine. ${ }^{257}$ Finding a nonfrivolous claim should not be too challenging for most lawyers, particularly if the standard for

252. See, e.g., Columbia Gas of Pa. v. Am. Int'l Grp., No. 10-1131, 2011 WL 294520, at *2 (W.D. Pa. Jan. 27, 2011) ("Duplicative litigation, and the potential for different outcomes in different courts, is undesirable for apparent reasons.").

253. FED. R. CIV. P. 8(a)(2).

254. See Ashcroft v. Iqbal, 556 U.S. 662, 678 (2009) ("Rule 8 marks a notable and generous departure from the hyper-technical, code-pleading regime of a prior era ...."); Venn-Severin Mach. Co. v. John Kiss Sons Textile Mills, Inc., 2 F.R.D. 4 , 5 (D.N.J. 1941) ("[The Federal Rules of Civil Procedure] employ simplicity, conciseness and directness and technical forms are eschewed.").

255. Nissan N. Am., Inc. v. Andrew Chevrolet, Inc., 589 F. Supp. 2d 1036, 1040 (E.D. Wis. 2008) (describing the benefits of the heart of the complaint rule).

256. Kelly Inv., Inc. v. Cont'l Common Corp., 315 F.3d 494, 497 n.4 (5th Cir. 2002).

257. Riley v. Dozier Internet Law, PC, 371 F. App’x 399, 404 n.2 (4th Cir. 2010). 
"frivolous" in this context is akin to the standard of Federal Rule of Civil Procedure $11 .{ }^{258}$ As one district court colorfully put it, "it would be the tail wagging the $\operatorname{dog}$ if the presence of a subordinate claim were sufficient to require a federal court to hear primary claims that it has determined are better resolved elsewhere." 259 This rule would "encourage abuses, as savvy litigants would recognize that creative pleading of tagalong coercive claims in tandem with declaratory judgment claims was a surefire means of circumventing Wilton and preserving a federal forum, notwithstanding parallel state proceedings." 260 If a court applied this approach, a litigant would not have to be particularly clever to work a claim for nondeclaratory relief into the complaint to avoid Brillhart/Wilton. Litigants would, in practice, find evading Brillhart/Wilton "far too easy."

The Seventh and Ninth Circuits' jurisdictional-independence approach, given its functional similarity to the heart of the complaint rule, should provide some limits on creative pleading. It requires a plaintiff to be able to state a claim for nondeclaratory relief over which a federal court would have jurisdiction independent of the claim for declaratory relief. But this approach is still "too inflexible."262 Creative pleading is not that hard for even decent lawyers. Thus, although this approach is a step in the right direction, it ultimately falls short in fully preventing litigants from manipulative pleadings.

Lastly, the surgical approach of the First Circuit also fails to prevent a potential gamesmanship. Under this approach, a court could decide not to hear the claims for declaratory relief, but if the plaintiff included claims for nondeclaratory relief, then the court is left having to exercise jurisdiction over the case unless the court could abstain under Colorado River. Given the narrowness of Colorado River abstention, a court may be forced to exercise jurisdiction over the claims for nondeclaratory relief. If the court is required to hear the case, then a plaintiff may well have achieved whatever strategic advantage the plaintiff sought by filing a case in federal court, even if the claim for declaratory relief will not be

258. See, e.g., Townsend v. Holman Consulting Corp., 929 F.2d 1358, 1362 (9th Cir. 1990) (en banc) ("The word 'frivolous' does not appear anywhere in the text of the Rule; rather, it is a shorthand that this court has used to denote a filing that is both baseless and made without a reasonable and competent inquiry." (emphasis added)).

259. Franklin Commons E. P'ship v. Abex Corp., 997 F. Supp. 585, 592 (D.N.J. 1998).

260. Lexington Ins. Co. v. Rolison, 434 F. Supp. 2d 1228, 1237 (S.D. Ala. 2006).

261. Nissan N. Am., Inc. v. Andrew Chevrolet, Inc., 589 F. Supp. 2d 1036, 1040 (E.D. Wis. 2008).

262. Id. 
decided. Thus, although all gamesmanship in this area typically involves multiple judicial systems, the gamesmanship to which this particular approach is subject is particularly problematic in this regard: this approach deals effectively with keeping a court from being forced to decide a claim for declaratory relief, but it does not keep a plaintiff from using a case in federal court as part of a larger plan, in conjunction with a case in a state court, to manipulate litigation (broadly defined) against a particular defendant.

\section{Providing Flexibility to Reach a Just Result}

A fourth consideration in determining how best to handle mixedcomplaint cases is the need to provide federal courts with the necessary flexibility to reach just results. Indeed, reaching a just result in each case is paramount. ${ }^{263}$ Given the importance of reaching the correct result in each case, courts need an approach to mixed-complaint cases that does not unnecessarily hinder their ability to reach the result they determine is correct on the particular facts of a case.

The heart of the complaint rule guarantees this flexibility, which is one feature of it that has drawn many district courts to adopt it. ${ }^{264}$ The heart of the complaint rule is a fact-driven approach that ensures a court can cut to the core of a complaint's allegations and apply the rule-either Brillhart/Wilton or Colorado River - that is more appropriate for the case. In other words, the court has the latitude to apply the doctrine that will reach whatever the court believes is the just result. This is not to suggest that a court will (or should) torture the analysis to reach the result that the court wants. ${ }^{265}$ Instead, the idea is that the court has the flexibility to reach what should be the legally correct and just result. ${ }^{266}$

263. See Wm. Grayson Lambert, Focusing on Fulfilling the Goals: Rethinking How Choice-ofLaw Regimes Approach Statutes of Limitations, 65 SYRACUSE L. REV. 491, 501 (2015) ("Deciding cases accurately is one of the most important jobs that a court has.").

264. See, e.g., Lexington Ins. Co., 434 F. Supp. 2d at 1237-38 ("One of the most desirable features of the 'heart of the action' rule is its flexibility, as it allows district courts to treat different cases differently based on the fundamental character of a particular action."); ITT Indus., Inc. v. Pac. Emp'rs Ins. Co., 427 F. Supp. 2d 552, 557 (E.D. Pa. 2006) ("The Court finds that the considerations underlying the decisions in Colorado River and Wilton regarding a district court's obligation to exercise jurisdiction over an action are better served by the fact-driven 'heart of the matter' approach than the application of a bright-line rule.").

265. Cf. Lambert, supra note 229, at 1293-94 (discussing the view of law that sees no difference between law and political views).

266. Someone who devotedly follows this no-distinction view (which is essentially a version of legal realism, $c f$. Oliver Wendell Holmes, Jr., The Path of the Law, 10 HARV. L. REV. 457 (1897)) will reject the idea that a "legally correct" result exists. But this person should also believe that a 
Ultimately, federal judges must be trusted to apply the law faithfully; ${ }^{267}$ otherwise, the entire federal judiciary would face far greater problems than whether courts were properly dealing with mixed-complaint cases.

Of course, too much flexibility can be a problem, either because the standards are too amorphous to be meaningful or because the standards are too difficult to apply. In the one other article addressing this topic, the proposed solution - applying a different approach based on the type of case, such as insurance litigation, securities litigation, or arbitrationrelated litigation ${ }^{268}$ - suffers from this second problem. Having a different approach for each type of substantive claim not only would prove complicated in practice, as courts and litigants would have to keep straight these varying standards, ${ }^{269}$ but also would require courts constantly to be addressing new types of cases to decide what approach applied to those claims. Moreover, this answer to the mixed-complaint question focuses solely on the underlying substance of a case, not the four systemic concerns that every mixed-complaint case raises and that are the basis of the analysis here.

This flexibility that the heart of the complaint rule provides does not, as the Fourth Circuit suggested, "deprive a plaintiff of access to a federal forum simply because he sought declaratory relief in addition to an injunction or money damages." ${ }^{270}$ A court would only abstain, even under Brillhart/Wilton, if a moving party proved that abstention was appropriate. Brillhart/Wilton does not provide some trump card to keep a court from hearing a case that should be heard, which is what the Fourth Circuit, as well as the three other circuits sharing the Fourth Circuit's view, implied. ${ }^{271}$

Ultimately, the heart of the complaint rule is neither amorphous nor complicated. It is simple to apply: a court examines a case to determine whether, at its core, the case is about declaratory or nondeclaratory relief, and then the court applies the appropriate abstention doctrine. Although

\footnotetext{
court will reach its desired result no matter the legal rule, so the legal framework is presumably unimportant (or at least less important) to this person, which means this entire Article is something that person would see as nothing but a pointless academic exercise.

267. Cf. 28 U.S.C. $§ 453$ (2012) (providing the oath for federal judges).

268. See Mamone, supra note 16, at 368-75 (arguing that a single test is unwise because of the nature of abstention and the uniqueness of each case).

269. Although courts and litigants should ultimately be able to keep these standards straight, it would prove far more time consuming than having a single standard.

270. vonRosenberg v. Lawrence, 781 F.3d 731, 735 (4th Cir. 2015).

271. See id. ("We decline to adopt a rule that would transform that thoroughness [of including claims for both declaratory and nondeclaratory relief] into a handicap.”).
} 
some cases may be debatable at what the core of the case seeks, such disagreement is possible with virtually any legal rule that is not an absolute rule. ${ }^{272}$ This room for disagreement does not make the heart of the complaint rule too mushy to apply meaningfully or too complicated to apply accurately.

As with the previous three standards for evaluating these approaches, the other approaches to mixed-complaint cases fall short. Starting with the Second, Fourth, Fifth, and Tenth Circuits' bright-line approach, a court has no flexibility: it must apply Colorado River. Thus, even if a court believed not exercising jurisdiction was the right answer, the court would be required to exercise jurisdiction unless the "stringent" standard of Colorado River is met. ${ }^{273}$ This lack of flexibility suggests one of two outcomes when a court should not exercise jurisdiction over a mixedcomplaint case: either the court will faithfully apply Colorado River and exercise jurisdiction over the case despite any well-founded misgivings or the court will contort the Colorado River analysis to abstain. Neither result is desirable.

What this approach does offer, of course, is a clear rule. ${ }^{274}$ Such bright-line approaches are certainly beneficial in some respects. ${ }^{275}$ For example, they "foster consistency throughout the courts and because they alert parties to what is allowed and what is not in the eyes of the law."276 Although bright-line rules are often preferable because they provide more predictability for courts and litigants,${ }^{277}$ bright-line rules can also lead to more unpalatable results, ${ }^{278}$ particularly in issues that can be as fact-intensive as mixed-complaint cases. Given the fact-intensive nature of a mixed-complaint case and the fact that these cases, while important,

272. Recall that even the Fifth Circuit has adopted exceptions to its bright-line rule for mixed complaints.

273. Gulfstream Aerospace Corp. v. Mayacamas Corp., 485 U.S. 271, 289-90 (1988).

274. See Mamone, supra note 16, at 364 (noting how this approach provides a bright-line rule to the problem of mixed complaints).

275. Field, supra note 221, at 611 ("Federal court procedural, especially jurisdictional ones, need to be governed by clear, effective, and fair rules.").

276. Christopher Bingham Galligan, Case Summary, FTC v. Watson Pharmaceuticals 677 F.3d 1298 (11th Cir. 2012), 23 DePaul J. Art, TeCh. \& InTELl. Prop. L. 491, 506 (2013); cf. Arizona v. Roberson, 486 U.S. 675, 682-83 (1988) (discussing the benefits of a bright-line rule in criminal procedure).

277. See, e.g., Lambert, supra note 263, at 530-34 (arguing that a clear rule is important in determining which statute of limitations applies in a choice-of-law regime).

278. Cf. Russell Corp. v. Am. Home Assurance Co., 264 F.3d 1040, 1050 (11th Cir. 2001) ("There are several such bright line limitations on federal removal jurisdiction (e.g. the removal bar for in-state defendants and the one year time limit for diversity removals) that some might regard as arbitrary and unfair.”). 
do not yet threaten to overwhelm federal courts' dockets, providing flexibility for courts to get the answer right outweighs the benefits of a bright-line rule in this particular situation.

Next, as for the Seventh and Ninth Circuit's approach, it provides flexibility only when claims for nondeclaratory relief have no independent jurisdictional basis. Given the potential for creative pleading, ${ }^{279}$ this standard could leave courts often facing a situation in which a plaintiff has found a jurisdictional hook for a claim for nondeclaratory relief, leaving the court unable to apply Brillhart/Wilton and unable to abstain under Colorado River, despite having the firm conviction that not deciding the case is the better option. ${ }^{280}$

And finally, as for the First Circuit's approach, this rule gives a court flexibility to deal with the claim for declaratory relief, but it still leaves a court having to apply Colorado River when evaluating the claims for nondeclaratory relief. Of course, those claims are premised on jurisdictional statutes ${ }^{281}$ that do not provide the flexibility of 28 U.S.C. $\S$ 2201 , but when concerns about procedural gamesmanship are frequently at the center of a court's thinking, ${ }^{282}$ being left to apply Colorado River may still allow a litigant to keep a case in federal court when practical considerations suggest that is not the proper outcome.

\section{CONCLUSION}

Each of these four approaches to mixed complaints has some rationale foundation. Each has some benefits. Each has some drawbacks. But ultimately, the heart of the complaint approach "is the most appropriate and the most readily reconcilable with applicable legal principles." 283 Given the array of concerns facing courts, this approach best strikes the balance of preserving the unique language that Congress used in $\S 2201$, promoting the wise use of judicial resources, preventing manipulation of litigation, and providing courts the needed flexibility for

279. See supra Part III.C (discussing the possibilities of procedural gamesmanship).

280. Columbia Gas of Pa. v. Am. Int'1 Grp., No. 10-1131, 2011 WL 294520, at *2 (W.D. Pa. Jan. 27, 2011) ("'[T]he 'independent claim' approach, which will often—and likely would, in this case - result in an unsought, de facto severance or bifurcation of related claims between state and federal fora, is also unsatisfactory.").

281. In most cases, these claims would be based on either 28 U.S.C. $\S 1331$ or 28 U.S.C. $\S$ 1332. See supra notes $212-13$ and accompanying text.

282. Lexington Ins. Co. v. Rolison, 434 F. Supp. 2d 1228, 1237-38 (S.D. Ala. 2006) (discussing the need for a rule that allows a court to confront attempts to manipulate litigation).

283. Id. at 1237 . 
reaching the correct result. As instances of mixed complaints are likely to rise as judicial caseloads get larger, courts must have a rule that allows them to deal with these cases fairly and efficiently. The heart of the complaint approach is that rule. 